Article

\title{
Benefits of Ryegrass on Multicontaminated Soils Part 1: Effects of Fertilizers on Bioavailability and Accumulation of Metals
}

\author{
Christophe Waterlot ${ }^{1,2, * \mathbb{D}}$ and Marie Hechelski ${ }^{1}$ \\ 1 Laboratoire Génie Civil et géoEnvironnement (LGCgE), Yncréa Hauts-de-France, \\ Institut Supérieur d'Agriculture, 48 Boulevard Vauban, 59046 Lille CEDEX, France; \\ marie.hechelski@yncrea.fr \\ 2 Equipe Biotechnologie et Gestion des Agents Pathogènes en agriculture (BIOGAP), Yncréa Hauts-de-France, \\ Institut Supérieur d'Agriculture, 48 Boulevard Vauban, 59046 Lille CEDEX, France \\ * Correspondence: christophe.waterlot@yncrea.fr; Tel.: +33-3-28-38-48-01
}

Received: 19 August 2019; Accepted: 15 September 2019; Published: 18 September 2019

\begin{abstract}
Effects of three phosphorus fertilizers on the shoot biomass and on the accumulation of alkali, alkaline earth, and transition metals in the shoots and roots of ryegrass were studied with two contaminated garden soils. Phosphates were added in sustainable quantities in order to reduce the environmental availability of carcinogenic metals (e.g., $\mathrm{Cd}$ and $\mathrm{Pb}$ ) and to enhance the bioavailability of alkali and alkaline earth metals as well as micronutrients needed by plants. Addition of $\mathrm{Ca}\left(\mathrm{H}_{2} \mathrm{PO}_{4}\right)_{2}$ was the most convenient way to (i) limit the concentration of $\mathrm{Cd}$ and $\mathrm{Pb}$, (ii) keep constant the transfer of macro- and micronutrient from the soil to the ryegrass shoots, (iii) decrease the availability of metals, and (iv) increase the ratio values between potential Lewis acids and $\mathrm{Cd}$ or $\mathrm{Pb}$ in order to produce biosourced catalysis. For instance, the real phytoavailability was reduced by $27 \%-57 \%$ and $64.2 \%-94.8 \%$ for $\mathrm{Cd}$ and $\mathrm{Pb}$, respectively. Interestingly, the real phytoavailability of $\mathrm{Zn}$ was the highest in the least contaminated soils. Even if soils were highly contaminated, no visual toxicity symptoms were recorded in the growing ryegrasses. This indicates that ryegrass is suitable for the revegetation of contaminated gardens. To promote the sustainable ryegrass production on contaminated soils for production of new organic fragrance and drugs in green processes according to REACH (Registration, Evaluation, Authorisation, and Restriction of Chemicals) regulation, two processes should be recommended: assisted phytostabilization of the elements, and then assisted phytoextraction by using chelators.
\end{abstract}

Keywords: contaminated soil; metal transition; nutrient; phosphorus; amendment; ryegrass bioavailability

\section{Introduction}

Hyperaccumulators are mainly used in phytoextraction because they can contain up to $1 \%-2 \%$ of potentially toxic elements (PTEs). This advantage is combined with some drawbacks since there is no clear agronomic recommendation to produce hyperaccumulating plants. Consequently, the biomass of such plants is often low. The tolerant plants, in turn, do not accumulate PTEs as efficiently because they produce higher biomass yields as response to fertilizers or specific amendments. Thus, they are usually used in phytoremediation of soils contaminated by PTEs. Among the tolerant plants, ryegrass is currently used as green waste to make compost, to prevent the entrainment of windblown contaminated dust and the soil erosion, and to create public open space/parkland. It was selected for two mains reasons: its importance as a grazing crop and its preconization as a suitable plant for the revegetation of contaminated soils from metallurgical sites [1-3]. Among the 10 species of grass in the 
Poaceae family, the genus Lolium is one of the most known grasses used in the world as forage and lawn grasses. In France and in Europe, pasture and lawn seed are composed of annual ryegrass (Lolium multiflorum) and perennial ryegrass (Lolium perenne L.). Although defined as a non-hyperaccumulator plant, Lolium perenne L. has a strong resistance for PTEs. It was studied in assisted phytoextraction using biosurfactant (rhamnolipid), inorganic and organic chelatants (sulfates, citric acid, histidine, EDDS, EDTA, DTPA, NTA), chitosan or its derivatives, nanomaterials, hormones, and microbial agents with the aim at improving the translocation factor [4-8]. Lolium perenne L. has also been studied in rhizoremediation and in assisted phytostabilization [9-11]. The key of success of these technologies (used alone or in combination) lies also in its ability to reduce soil erosion, to enhance microbial activities in soils, and to improve soil fertility and carbon storage [12]. Remediation of contaminated soils by a combinational approach, using physical or chemical and biological technologies together with ryegrass [13-15] is used in phytoremediation of (i) soils contaminated by organic pollutants [16] and (ii) co-contaminated soils [17].

Emissions of dusts by two former smelters in the North of France have led to a significant increase of PTE concentrations in soils. Due to the accumulation of these pollutants in agricultural crops for foodstuffs, a high proportion of them did not comply with the European legislation $[18,19]$. Accumulation of PTEs in homegrown vegetables was demonstrated, and it was highlighted that most of the vegetables produced in kitchen gardens did not comply with the European foodstuff legislation [18]. This problem is not limited to northern France, but is present all over the world [20]. There are so challenges in assessing the health risks of consuming vegetables in metal-contaminated areas and, depending on the results, to make quick and good decisions about the management of these contaminated areas, including their reconversion.

Since phosphorus $(\mathrm{P})$ amendments have been described as a promising technique to immobilize PTEs like $\mathrm{Pb}$ in contaminated soils, soluble, insoluble, and mixed phosphates were used to study their effects on mobility, bioavailability, and bioaccessibilty of PTEs [21-24]. Although $\mathrm{H}_{3} \mathrm{PO}_{4}$ was used as amendment, it is worth mentioning that it is never used as a P fertilizer. In fertilizers and in soil solution, $\mathrm{P}$ anion is typically either as $\mathrm{H}_{2} \mathrm{PO}_{4}{ }^{-}$or $\mathrm{HPO}_{4}{ }^{2-}$, depending on soil $\mathrm{pH}$. Also mineralization of organic $\mathrm{P}$ compounds produces phosphate anions that are prone to be (ad)sorbed, specifically onto the surface of poorly crystalline (hydr)oxides of $\mathrm{Al}$ or Fe according to a ligand-exchange mechanism. As for its counter-ions (e.g., $\mathrm{K}^{+}, \mathrm{NH}_{4}{ }^{+}, \mathrm{Na}^{+}$), they are important plant nutrients in soils because they are absolutely needed by plants. Utilization of phosphates has benefits in the long-term [25-27]. Nevertheless, soluble phosphates may be a potential source of eutrophication of groundwater and surface waters and mitigate out of the soil in runoff $[28,29]$. On the other hand, the use of insoluble phosphates is not a relevant option to maintain the soil productivity. The plant takes nutrients from the soil solution and not directly from the surface of solid material. However, it is noteworthy that $\mathrm{P}$ in the solution phase tends to be in equilibrium with $\mathrm{P}$ (ad)sorbed onto the surface of amorphous hydr(oxides) of $\mathrm{Al}$ and Fe. Depending on the P saturation degree of the sorbent surface, the concentration of soluble $\mathrm{P}$ is variable. Consequently, a relevant strategy consists of using moderately soluble phosphates like mono- and dicalcium phosphates $\left(\mathrm{Ca}\left(\mathrm{H}_{2} \mathrm{PO}_{4}\right)_{2}\right.$ and $\left.\mathrm{CaHPO}_{4}\right)$, respectively named calcium dihydrogen phosphate and calcium hydrogen phosphate. The solubilization of these two crystalline phosphates in soil $\left(\mathrm{Ca}\left(\mathrm{H}_{2} \mathrm{PO}_{4}\right)_{2} \leftrightarrows \mathrm{Ca}^{2+}+2 \mathrm{H}_{2} \mathrm{PO}_{4}^{-} ; \mathrm{CaHPO}_{4} \leftrightarrows \mathrm{Ca}^{2+}+\mathrm{HPO}_{4}{ }^{2-}\right)$ are $18 \mathrm{~g} / 100 \mathrm{~g}$ and $0.14 \mathrm{~g} / 100 \mathrm{~g}$, respectively, and the equilibrium constants are defined as log Ksp $=-1.14$ and $\log \mathrm{Ksp}=-6.6$ [30]. The current study was based on this strategy. Phosphates were added into the soil with a new approach in order to prevent the mobilization of carcinogenic compounds (e.g., $\mathrm{Cd}$ ) and to limit their concentration in the aerial biomass of plants. The effects of $\mathrm{Ca}\left(\mathrm{H}_{2} \mathrm{PO}_{4}\right)_{2}, \mathrm{CaHPO}_{4}$, and the mixture of both phosphates on the accumulation of PTEs ( $\mathrm{Al}, \mathrm{Cd}, \mathrm{Cu}, \mathrm{Mn}, \mathrm{Pb}$, and $\mathrm{Zn}$ ) and macroand micronutrients $(\mathrm{Fe}, \mathrm{Na}, \mathrm{K}, \mathrm{Ca}, \mathrm{Mg}$ ) in the shoots and roots of ryegrass (Lolium perenne $\mathrm{L}$.) were reported. Three indicators were used to evaluate the phytoavailability of metals in order to define the strategy that can be used to manage contaminated soils, with the aim at using the biomass of 
ryegrass as a raw material in the manufacturing of biosourced catalyst to produce molecules of interest (pharmaceuticals, cosmetics).

\section{Materials and Methods}

\subsection{Context of the Study and Soil Analysis}

For more than a century, two lead and zinc smelters in northern France (Metaleurop Nord, Noyelles-Godault and Nyrstar, Auby) generated significant quantities of dust that have led to substantial contamination of the surrounding soils by PTEs like As, Cd, Co, Cr, Hg, In, Pb, and Sb [31]. Since the closure of Metaleurop Nord, most of the crops grown on these soils still present concentrations of $\mathrm{Cd}, \mathrm{Pb}$, and $\mathrm{Zn}$ higher than the maximum threshold allowed for food and feed [18,32]. In few cases, gardeners decided to change their cultural practices, while others took the decision to stop the gardening and to sow grass. In this context, two composite samples $(0-25 \mathrm{~cm})$ located not far from Metaleurop (Noyelles Godault, $3 \mathrm{~km}$ ) and Nyrstar (Auby, $2 \mathrm{~km}$ ) were sampled with a $6 \mathrm{~cm}$ diameter stainless steel auger and consisted of 10 cores, randomly taken in two kitchen garden soils (G1 and G2). Each composite sample was air-dried at a temperature below $40^{\circ} \mathrm{C}$ and then crushed to pass through a $10 \mathrm{~mm}$ stainless steel sieve and crushed to pass through a $2 \mathrm{~mm}$ stainless steel sieve for the determination of physical and chemical parameters. Then, the composite samples were passed through a $250 \mu \mathrm{m}$ sieve with an ultracentrifugal mill (ZM 200, Retsch, Hann, Germany) for the determination of total and extractable metal concentrations. After adding $5 \mathrm{~g}$ samples to $25 \mathrm{~mL}$ distilled water, the mixture was mechanically shaken for $5 \mathrm{~min}$, allowed to settle for $2 \mathrm{~h}$, and the $\mathrm{pH}$ of supernatant was measured in triplicates. The $\mathrm{CaCO}_{3}$ content was determined by measuring the volume of $\mathrm{CO}_{2}$ released by the reaction with $\mathrm{HCl}$, handling a Bernard calcimeter [33]. The cation exchange capacity (CEC) was determined after percolation of $1.0 \mathrm{~mol} \mathrm{~L}^{-1}$ ammonium acetate solution at $\mathrm{pH} 7$ [34]. The organic matter content was determined by dry combustion after burning $50 \mathrm{mg}$ samples at $1000{ }^{\circ} \mathrm{C}$ in the presence of $\mathrm{O}_{2}$ [35]. Assimilable $\mathrm{P}$ (expressed in $\mathrm{g}_{2} \mathrm{O}_{5} \mathrm{~kg}^{-1}$ of soil) was measured using an extraction by ammonium oxalate solution and spectrocolorimetric determination, according to the NF X 31-161 [36]. Particle size distribution was obtained through sedimentation and sieving, following the NF X 31-107 standard [37] by the INRA Soil Analysis Laboratory (Arras, France). Briefly, these soils had a clayey, sandy, loamy texture, although differed in the percentage of clay (Table 1). The $\mathrm{pH}$ of G1 and G2 was close to neutral, and the total carbonate content was 2.3-fold higher in G2 than in G1. This soil had the lowest cation-exchange capacity $\mathrm{cmol}^{+} \mathrm{kg}^{-1}(24.1$ vs. $12.5 \mathrm{cmol}^{+} \mathrm{kg}^{-1}$ for G1). The organic matter was slightly higher in the G2 topsoil than in G1, which presented $40 \%$ more $\mathrm{P}_{2} \mathrm{O}_{5}$ than in $\mathrm{G} 2\left(290 \mathrm{mg} \mathrm{P}_{2} \mathrm{O}_{5} \mathrm{~kg}^{-1}\right.$ vs. $\left.207 \mathrm{mg} \mathrm{P}_{2} \mathrm{O}_{5} \mathrm{~kg}^{-1}\right)$.

Table 1. Physicochemical parameters of G1 and G2 soils.

\begin{tabular}{ccccccccccc}
\hline Soil & Clay $^{\mathbf{a}}$ & $\begin{array}{c}\text { Coarse } \\
\text { Silt }^{\mathbf{a}}\end{array}$ & $\begin{array}{c}\text { Fine } \\
\text { Silt }^{\mathbf{a}}\end{array}$ & $\begin{array}{c}\text { Coarse } \\
\text { Sand }^{\mathbf{a}}\end{array}$ & $\begin{array}{c}\text { Fine } \\
\text { Sand }\end{array}{ }^{\mathbf{a}}$ & $\mathbf{p H}$ & $\mathbf{C a C O}_{3}{ }^{\mathbf{a}}$ & $\mathbf{C E C}$ & $\mathbf{O M}$ & $\mathbf{P}_{\mathbf{2}} \mathbf{O}_{5}{ }^{\mathbf{b}}$ \\
\hline $\mathrm{G} 1$ & 189 & 315 & 190 & 110 & 196 & $7.39 \pm 0.03$ & $7.2 \pm 0.1$ & $23.8 \pm 1.2$ & $71.2 \pm 1.3$ & $290 \pm 2$ \\
$\mathrm{G} 2$ & 288 & 324 & 196 & 45 & 147 & $7.21 \pm 0.02$ & $16.2 \pm 0.2$ & $12.5 \pm 1.2$ & $95.8 \pm 2.0$ & $207 \pm 2$ \\
\hline
\end{tabular}

${ }^{\mathrm{a}} \mathrm{g} \mathrm{kg}^{-1} ;{ }^{\mathrm{b}} \mathrm{mg} \mathrm{kg}^{-1}$; CEC: Cation-exchange capacity in $\mathrm{cmol}^{+} \mathrm{kg}^{-1}$; OM: Organic matter. $\mathrm{pH}, \mathrm{CaCO}_{3}, \mathrm{CEC}, \mathrm{OM}$ and

$\mathrm{P}_{2} \mathrm{O}_{5}$ were expressed as mean and standard deviation $(n=3)$.

Digestion of soil samples was performed using $\mathrm{HNO}_{3} / \mathrm{H}_{2} \mathrm{O}_{2} / \mathrm{HCl}$ hot-block (HotBlock ${ }^{\mathrm{TM}}$ Environmental Express ${ }^{\circledR}$ SC100, Charleston, SC, USA) digestion procedure, following the EPA 3050B method [38] with slight modifications. Briefly, $0.6 \mathrm{~g}$ of soil sample was acid-digested with nitric acid $\left(\mathrm{HNO}_{3}, 70 \%, 6 \mathrm{~mL}\right)$ and heated at $90 \pm 5{ }^{\circ} \mathrm{C}$ for $15 \mathrm{~min}$. After cooling to less than $70{ }^{\circ} \mathrm{C}, 3 \mathrm{~mL}$ of $\mathrm{HNO}_{3}$ was added, and the mixture was heated to $90 \pm 5^{\circ} \mathrm{C}$ without boiling for $30 \mathrm{~min}$. In absence of red vapor, the temperature was then maintained for $2 \mathrm{~h}$. After cooling to less than $50^{\circ} \mathrm{C}, 1.2 \mathrm{~mL}$ of water and $1.8 \mathrm{~mL}$ of $\mathrm{H}_{2} \mathrm{O}_{2}(30 \%)$ were slowly added. The solution was heated until effervescence subsided. After cooling, $6 \mathrm{~mL}$ of $12 \mathrm{M} \mathrm{HCl}$ was added, and the solution was heated at $90 \pm 5^{\circ} \mathrm{C}$ for 
$15 \mathrm{~min}$. After cooling to room temperature, the volume was adjusted to $25 \mathrm{~mL}$ with ultra-pure water, and the digested-solutions were filtered over an acetate Millipore membrane $(0.45 \mu \mathrm{m}$ porosity) and were stored at $4{ }^{\circ} \mathrm{C}$ in acid-washed plastic bottles prior to analysis. Because the chemical procedure used to determine the total concentration of PTEs does not produce reliable information on the bioavailable reserves or on those becoming bioavailable in long run, bioavailable metals were determined according to the rhizosphere-based extraction protocol [39]. Briefly, soils samples $(2 \mathrm{~g})$ were mixed with $20 \mathrm{~mL}$ of $0.01 \mathrm{M}$ low-molecular-weight organic acids in mixture (LMWOAs; acetic, lactic, citric, malic, formic acids with the following respective molar ratio 4:2:1:1:1). The soil suspension was shaken for $16 \mathrm{~h}$, was centrifuged at $4530 \mathrm{rpm}$ for $20 \mathrm{~min}$, filtrated, and stored until analysis.

\subsection{Soil Amendment and Design of the Incubation Experiment}

Phosphates (calcium dihydrogen phosphate $\left(\mathrm{Ca}\left(\mathrm{H}_{2} \mathrm{PO}_{4}\right)_{2} ; \mathrm{P}_{1}\right)$, calcium hydrogen phosphate $\left(\left(\mathrm{CaHPO}_{4}\right) ; \mathrm{P}_{2}\right)$, and a mixture of these two compounds $\left(75 / 25 ; \mathrm{P}_{3}\right)$ were added as reagent-grade. Each amendment was applied to soils in five replicates $(n=5)$ at a 3:5 molar ratio of $\mathrm{P} /$ metal, according to the recommendation of Ma et al. [40]. Amended and unamended soils were aged for 8 weeks prior to planting in a greenhouse and were maintained at $60 \%$ field capacity with tap water (electrical conductivity, $10 \mathrm{dS} \mathrm{m}^{-1}$; $\left.\mathrm{pH}, 7 ;(\mathrm{Cd})=0.8 \mu \mathrm{g} \mathrm{L}^{-1} ;(\mathrm{Pb})=1.7 \mu \mathrm{g} \mathrm{L}^{-1}\right)$. Eight weeks after the amendment, each soil was homogenized, and $0.225 \mathrm{~g}$ of ryegrass (Lolium perenne L.) was sown into each of the 40 pots (diameter: $12 \mathrm{~cm}$; height: $12 \mathrm{~cm} ; 2$ soils $\times 4$ treatments $\times 5$ replicates), containing $400 \mathrm{~g}$ of soils. The plants were grown for 10 weeks in a greenhouse at $20-27^{\circ} \mathrm{C}$, and the soil moisture was maintained at $60 \%$ field capacity with tap water. The experimental design was randomized twice per week in order to be exposed to uniform environmental conditions. After 10 weeks of growth, the plants were harvested. In the same time, the roots of ryegrass were sampled, rinsed with distilled water to remove any soil particle or dust. Plant tissues were oven-dried at $40{ }^{\circ} \mathrm{C}$ and crushed with an oscillating crusher in order to sieve them below $315 \mu \mathrm{m}$. Digestion of plant tissues was performed using $\mathrm{HNO}_{3} / \mathrm{H}_{2} \mathrm{O}_{2}$ hot-block digestion procedure. In this procedure, $300 \mathrm{mg}$ of plant tissues was transferred to a $50 \mathrm{~mL}$ digestion tube. Nitric acid $(70 \%, 5 \mathrm{~mL})$ was added, and the mixture was heated at $65{ }^{\circ} \mathrm{C}$ for $20 \mathrm{~min}$ and then, at $90^{\circ} \mathrm{C}$ for $45 \mathrm{~min}$. After cooling to less than $50{ }^{\circ} \mathrm{C}, 1.2 \mathrm{~mL}$ of water and $1.8 \mathrm{~mL}$ of $\mathrm{H}_{2} \mathrm{O}_{2}(30 \%)$ were slowly added. The solution was heated at $90^{\circ} \mathrm{C}$ for $45 \mathrm{~min}$. After cooling to room temperature, the volume was adjusted to $25 \mathrm{~mL}$ with ultra-pure water, filtered, and stored until analysis.

\subsection{Phytoavailability of Metals}

The plant's ability to uptake metals was calculated from the concentration of metals in plant tissues and the concentration of metals in soils [41]. The real phytoavailability of metals was expressed as percentage of metal mass absorbed by the aboveground biomass of ryegrass with respect to the metal mass in soil per each pot [42]. The ability of ryegrass to transfer metals from the roots to its aboveground parts was defined as the ratio of the metal concentrations in shoots to roots [41]. Note that the concentration of metals was expressed in $\mathrm{mg} \mathrm{kg}^{-1}$, biomass and soil mass were expressed in $\mathrm{g} \mathrm{pot}^{-1}$ and $\mathrm{kg} \mathrm{pot}^{-1}$, respectively.

\subsection{Analytical Techniques and Quality Control}

The metal concentrations in soil and plant digests were determined by a flame atomic absorption spectrometer (FAAS, AA-6800, Shimadzu, Tokyo, Japan). High-intensity boosted-discharge hollow-cathode lamps $(\mathrm{Cd}, \mathrm{Pb}$, and $\mathrm{Zn}$; Hamamatsu, Iwata, Japan) were used to avoid spectral interferences [43-45]. The lamps were operated between 6 and $12 \mathrm{~mA}$ for $\mathrm{Al}, \mathrm{Ca}, \mathrm{Cu}, \mathrm{Fe}, \mathrm{K}, \mathrm{Mg}, \mathrm{Mn}$, and $\mathrm{Na}$, and a deuterium lamp was used for the background correction. The limits of detection (LOD) and quantification (LOQ), respectively based on three and ten times the standard deviation of the blank $(n=10)$, are presented in Table 2 . The quality of the combined hot-block digestion procedure and analytical technique was evaluated by analyzing certified reference materials (CRM BCR 141 R, ERM $^{\circledR}$ CC141 and PCRM CTA-VTL-2). Metal concentrations in the digestion solution are summarized 
in Table 3. The metal concentrations in the three reference materials were generally in good agreement with the certified or indicative aqua regia soluble concentrations. The precision and the trueness values were found to be less than $9 \%$, except for Cd in the ERM ${ }^{\circledR}$ CC141 soil, in which the concentration was very low $\left(0.22 \pm 0.04 \mathrm{mg} \mathrm{kg}^{-1}\right.$ instead of $0.25 \pm 0.04 \mathrm{mg} \mathrm{kg}^{-1}$; Table 3).

\subsection{Statistical Analysis}

Significant differences between the treatments and the control were determined using a one-way ANOVA. Significance was reported at $p<0.05$. All statistical tests were performed using the software program XLSTAT 2017 (Addinsoft, Paris, France).

Table 2. Limits of detection (LOD) and quantification (LOQ) in $\mu \mathrm{g} \mathrm{L}^{-1}$.

\begin{tabular}{lccccccccccc}
\hline Element & $\mathbf{C d}$ & $\mathbf{P b}$ & $\mathbf{Z n}$ & $\mathbf{A l}$ & $\mathbf{C a}$ & $\mathbf{C u}$ & $\mathbf{F e}$ & $\mathbf{K}$ & $\mathbf{M g}$ & $\mathbf{M n}$ & $\mathbf{N a}$ \\
\hline LOD & 2.1 & 41.0 & 1.5 & 156.0 & 32.2 & 49.0 & 41.9 & 5.0 & 12.0 & 4.1 & 5.0 \\
LOQ & 7.0 & 136.7 & 5.0 & 520.0 & 107.3 & 163.3 & 139.7 & 16.7 & 40.0 & 13.7 & 16.7 \\
\hline
\end{tabular}


Table 3. Certified and measured concentrations of PTEs $\left(\mathrm{mg} \mathrm{kg}^{-1}\right)$ in reference materials—statistic indicators of the analytical quality.

\begin{tabular}{|c|c|c|c|c|c|c|c|c|c|c|c|c|}
\hline \multirow[t]{2}{*}{ Metal } & \multicolumn{4}{|c|}{ CRM BCR $141 \mathrm{R}$} & \multicolumn{4}{|c|}{ ERM $^{\circledR}$ CC141 } & \multicolumn{4}{|c|}{ PCRM CTA-VTL-2 } \\
\hline & $\begin{array}{l}\text { Certified } \\
\text { Value }\end{array}$ & $\begin{array}{c}\text { Obtained } \\
\text { Value }(n=3)\end{array}$ & $\begin{array}{l}\text { Precision } \\
(\%)\end{array}$ & $\begin{array}{c}\text { Trueness } \\
\text { (\%) }\end{array}$ & $\begin{array}{l}\text { Certified } \\
\text { Value }\end{array}$ & $\begin{array}{c}\text { Obtained } \\
\text { Value }(n=3)\end{array}$ & $\begin{array}{l}\text { Precision } \\
(\%)\end{array}$ & $\begin{array}{c}\text { Trueness } \\
(\%)\end{array}$ & $\begin{array}{l}\text { Certified } \\
\text { Value }\end{array}$ & $\begin{array}{c}\text { Obtained } \\
\text { Value }(n=3)\end{array}$ & $\begin{array}{c}\text { Precision } \\
(\%)\end{array}$ & $\begin{array}{c}\text { Trueness } \\
(\%)\end{array}$ \\
\hline $\mathrm{Al}$ & $32,200 \pm 600^{a}$ & $32,412 \pm 135$ & 0.41 & -0.66 & - & - & - & - & $1682^{b}$ & $1614 \pm 50$ & 3.01 & 4.04 \\
\hline $\mathrm{Cd}$ & $13.96 \pm 0.46$ & $13.31 \pm 0.09$ & 0.67 & -4.66 & $0.25 \pm 0.04$ & $0.22 \pm 0.04$ & 18.20 & -13.60 & $1.52 \pm 0.17$ & $1.50 \pm 0.13$ & 8.70 & -1.31 \\
\hline $\mathrm{Cu}$ & $46.9 \pm 1.8$ & $44.6 \pm 1.6$ & 3.59 & -4.90 & $12.4 \pm 0.9$ & $12.7 \pm 0.3$ & 2.36 & 0.24 & $18.2 \pm 0.9$ & $19.8 \pm 0.2$ & 1.01 & 8.79 \\
\hline $\mathrm{Fe}$ & $25,850 \pm 400$ & $24,955 \pm 1605$ & 6.43 & -3.46 & - & $11901 \pm 78$ & 0.66 & - & $1083 \pm 33$ & $1088 \pm 35$ & 3.21 & 0.46 \\
\hline $\mathrm{Mn}$ & $653 \pm 20$ & $664 \pm 7$ & 1.05 & 1.68 & $387 \pm 17$ & $400 \pm 4$ & 1.00 & 3.36 & $79.7 \pm 2.6$ & $83.4 \pm 3.5$ & 4.20 & 4.60 \\
\hline $\mathrm{Pb}$ & $51.3 \pm 2.0$ & $50.0 \pm 1.2$ & 2.40 & -2.53 & $32.2 \pm 1.4$ & $30.6 \pm 1.7$ & 5.55 & -4.97 & $22.1 \pm 1.2$ & $21.8 \pm 1.2$ & 5.50 & -1.35 \\
\hline $\mathrm{Zn}$ & $270 \pm 8$ & $277 \pm 1.6$ & 0.57 & 2.59 & $50 \pm 4$ & $47 \pm 1$ & 2.12 & -6.00 & $43.0 \pm 2.1$ & $42.9 \pm 2.2$ & 5.13 & -0.23 \\
\hline
\end{tabular}

${ }^{\mathrm{a}}$ indicative value; ${ }^{\mathrm{b}}$ only one value. 


\section{Results and Discussion}

\subsection{Concentration of Transition, Alkali, and Alkaline Earth Metals and Aluminum in Soils}

Metal transitions were chemically defined as metals in the d-block of the periodic table $(\mathrm{Cd}, \mathrm{Cu}$, $\mathrm{Fe}, \mathrm{Mn}, \mathrm{Pb}, \mathrm{Zn})$. Alkali $(\mathrm{Na}, \mathrm{K})$ and alkaline earth $(\mathrm{Ca}, \mathrm{Mg})$ metals are in the first and the second period of this table, respectively, whereas aluminum ( $\mathrm{Al})$ is in the boron group. Due to the close proximity of the smelters and gardens ( $\mathrm{G} 1$ and $\mathrm{G} 2$ ), $\mathrm{Al}, \mathrm{Cd}, \mathrm{Cu}, \mathrm{Fe}, \mathrm{Mn}, \mathrm{Pb}$, and $\mathrm{Zn}$ were considered as PTEs, whereas $\mathrm{Na}, \mathrm{K}, \mathrm{Ca}$, and $\mathrm{Mg}$ were defined as macronutrients. It is noteworthy to mention that concentrations of $\mathrm{Cd}, \mathrm{Pb}, \mathrm{Zn}$, and $\mathrm{Cu}$ in $\mathrm{G} 1$ were 2.1-fold, 3.1-fold, 2.4-fold, and 1.9-fold higher than concentrations of these PTEs measured in the ploughed layer of contaminated cultivated soils around Nystar [31]. Concentrations of $\mathrm{Cd}, \mathrm{Pb}, \mathrm{Zn}$, and $\mathrm{Cu}$ in $\mathrm{G} 2$ were 2.2-fold, 3.1-fold, 7.0-fold, and 3.9-fold higher than concentrations of these PTEs measured in the ploughed layer of contaminated cultivated soils around Metaleurop Nord [31]. These results were consistent with those obtained in previous studies, in which the authors showed that the contamination level of kitchen garden soils was greater than that in agricultural soils located in the same environmental context [46]. Pelfrêne et al. [47] reported that the mean concentrations of $\mathrm{Mn}, \mathrm{Fe}$, and $\mathrm{Al}$ in agricultural soils $(n=390)$ located in the studied area were $370 \pm 140 \mathrm{mg} \mathrm{kg}^{-1}, 22,090 \pm 10,940 \mathrm{mg} \mathrm{kg}^{-1}$, and $9080 \pm 6360 \mathrm{mg} \mathrm{kg}^{-1}$, respectively. Regarding these concentrations, it may be accepted that similar concentrations of Mn were obtained in soils G1 and G2, whereas the concentrations of Fe and Al were significantly highest and lowest. Although heterogeneous and variable concentrations were highlighted in garden soils from the studied area [48], no significant difference between the concentrations of $\mathrm{Al}, \mathrm{Cd}, \mathrm{Cu}, \mathrm{Fe}, \mathrm{Mn} \mathrm{Pb}, \mathrm{Zn}, \mathrm{Na}, \mathrm{K}, \mathrm{Ca}$, and $\mathrm{Mg}$ in soils before potting was highlighted. Note that concentrations of $\mathrm{Cd}, \mathrm{Pb}, \mathrm{Zn}, \mathrm{Cu}, \mathrm{Ca}$, and $\mathrm{Mg}$ were higher in soil G2 than in soil G1 (1.24-fold, 3.21-fold, 1.94-fold, 2.39-fold, 3.45-fold, 1.93-fold, respectively), whereas Fe was the lowest in G2 (0.95-fold and 0.88-fold, respectively) and $\mathrm{Al}, \mathrm{Mn}, \mathrm{Na}$, and $\mathrm{K}$ were rather similar in the two soils.

\subsection{Biomass, Concentrations of Transition, Alkali, and Alkaline Earth Metals and Aluminum in the Ryegrass Shoots}

\subsubsection{Shoot Biomass of Ryegrass}

The shoots of ryegrass were cut ten weeks after sowing. The fresh weight biomass was from $23.5 \mathrm{~g}$ to $26.5 \mathrm{~g}$ for ryegrass grown on unamended and amended soils G1, whereas for soils G2, they were in the range $23-26.8 \mathrm{~g}$. In view of the different water content in the aerial parts of ryegrass, shoots were dried at $40{ }^{\circ} \mathrm{C}$ (Figure 1). The dried shoot mass of ryegrass grown on G1 and G2 was on average $8.57 \pm 052 \mathrm{mg}$ and $8.68 \pm 0.50 \mathrm{mg}$, respectively. In view of PTE concentrations in G1 and G2 soils (Table 4), these results revealed that the concentration of PTEs in the aerial parts of ryegrass did not only depend on the total concentration of PTEs in soils, but also on the bioavailable concentrations (soluble, labile, and exchangeable), as shown in other studies [6,9,49]. Moreover, due to the absence of visual toxicity symptoms (no noticeable wilting and slight leaf chlorosis), Lolium Perenne L. exhibited a metal tolerance when facing high PTE concentrations in soils. This finding correlated well with the fact that ryegrass was described as a suitable plant for the revegetation of contaminated soils from metallurgical sites [1]. The effects of phosphates on the biomass were the same for both soils, but were amendment-dependent (Figure 1). Calcium dihydrogen phosphate $\left(\mathrm{P}_{1}\right)$ significantly increased the shoot biomass, whereas a significant decrease was observed with calcium hydrogen phosphate $\left(\mathrm{P}_{2}\right)$. No significant effect was reported with the mixture of phosphates $\left(\mathrm{P}_{3}\right)$. The chemical properties of $\mathrm{P}_{1}$ and $\mathrm{P}_{2}$ are very easy to distinguish since the ratio $\mathrm{Ca} / \mathrm{P}$ values are 1.294 and 0.647 , respectively. According to Chen et al. [50], calcium phosphate with a $\mathrm{Ca} / \mathrm{P}$ ratio below 1.67 is considered as acid species. Consequently, the acidity of $\mathrm{P}_{2}$ is higher than that of $\mathrm{P}_{1}$. This theory was supported by the $\mathrm{pH}$ of the solution containing $\mathrm{P}_{1}$ and $\mathrm{P}_{2}$ for $\mathrm{G} 1$ (4.57 and 7.67, respectively) and G2 (4.11 and 8.05 , respectively). 


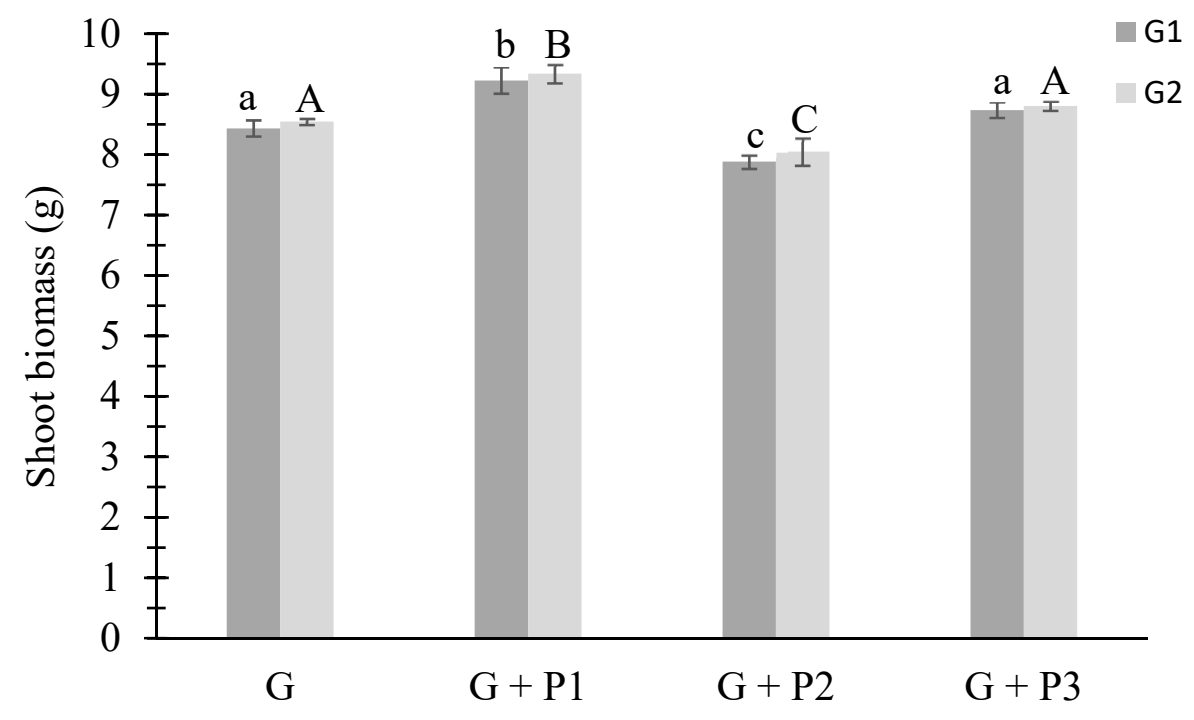

Figure 1. Effects of $P$ fertilizers in the fresh biomass of ryegrass shoots from G1 and G2 soils. Vertical bars indicate standard deviation $(n=5)$. Letters refer to significant differences $(p<0.05)$.

3.2.2. Concentrations of Transition, Alkali, and Alkaline Earth Metals and Aluminum in the Shoots of Ryegrass

Lolium perenne $\mathrm{L}$. grew on $\mathrm{G} 1$ and $\mathrm{G} 2$, and metals, like PTEs ( $\mathrm{Al}, \mathrm{Cd}, \mathrm{Cu}, \mathrm{Mn}, \mathrm{Pb}$, and $\mathrm{Zn}$ ), as well as macro- and micronutrients ( $\mathrm{Na}, \mathrm{K}, \mathrm{Ca}, \mathrm{Mg}$, $\mathrm{Fe}$ ) were measured in the shoots (Table 5). Although the concentrations of (i) $\mathrm{Cd}, \mathrm{Pb}, \mathrm{Zn}, \mathrm{Cu}$ were higher in $\mathrm{G} 2$ than in $\mathrm{G} 1$ and (ii) $\mathrm{Al}$ and $\mathrm{Mn}$ were similar in the two soils (Table 4), the concentrations of these PTEs (except for Pb) were higher in the shoots of ryegrass grown on G1 than on G2 (Table 5). This result reflects a better stability of PTEs in the soil G2 than in G1, which may be explained by the highest organic matter and clays contents in G2 (Table 1). Indeed, common clays, such as kaolin and phyllosilicates (montmorillonite, bentonite, attapulgite, sepiolite, vermiculite) were used in many studies for ex-situ and in-situ immobilization of PTEs in soils and for the hazard limitation of these pollutants to plants [51,52]. As shown in Table 5, the best effects of fertilizers on the phytoavailability of PTEs were obtained in soil G1, suggesting that the soluble and labile pools of PTEs were the greatest in this soil. The three phosphorus amendments significantly decreased the PTEs concentrations (except $\mathrm{Mn}$ ) and Fe in the shoots of ryegrass grown in G1. The best effects were obtained with $\mathrm{P}_{1}\left(\mathrm{Ca}\left(\mathrm{H}_{2} \mathrm{PO}_{4}\right)_{2}\right)$, which confirmed the successful ligand immobilization of divalent PTEs and so, the lowest accumulation of PTEs $[25,53,54]$. Moreover, $\mathrm{Ca}\left(\mathrm{H}_{2} \mathrm{PO}_{4}\right)_{2}$ is gradually transformed into more stable phosphates like octocalcium phosphates and apatites, which are known for their reactivity towards PTEs like $\mathrm{Pb}$ to form stable phosphates such as pyromorphite, unavailable for plants $[30,42,55]$. On the other hand, it can react with $\mathrm{Fe}, \mathrm{Al}$, and $\mathrm{Ca}$ to form secondary $\mathrm{P}$ minerals by precipitation [56]. This could explain the large decrease of $\mathrm{Fe}$ and $\mathrm{Ca}$ in the shoots of ryegrass grown on $\mathrm{G} 1$ and $\mathrm{G} 2$. The basic effects of $\mathrm{Ca}\left(\mathrm{H}_{2} \mathrm{PO}_{4}\right)_{2}$ may contribute to limit the concentration of macro- and microelements like $\mathrm{Zn}$ and $\mathrm{Fe}$ since it was the dominant species for $\mathrm{pH}$ between 4 and 5.5 [57]. 
Table 4. Concentration ( $\left.\mathrm{mg} \mathrm{kg}^{-1} ; n=5\right)$ of metal transition, alkali, and alkaline earth metals in soils G1 and G2 before the addition of phosphates.

\begin{tabular}{|c|c|c|c|c|c|c|c|c|c|c|c|c|c|c|c|c|c|c|c|c|c|c|c|c|}
\hline \multirow{2}{*}{$\frac{\text { Metal }}{\mathrm{Cd}}$} & \multicolumn{3}{|c|}{ Soil G1 } & \multicolumn{3}{|c|}{ Soil G1 + $P_{1}$} & \multicolumn{3}{|c|}{ Soil G1 + $P_{2}$} & \multicolumn{3}{|c|}{ Soil G1 $+P_{3}$} & \multicolumn{3}{|c|}{ Soil G2 } & \multicolumn{3}{|c|}{ Soil G2 $+P_{1}$} & \multicolumn{3}{|c|}{ Soil G2 $+P_{2}$} & \multicolumn{3}{|c|}{ Soil G2 $+P_{3}$} \\
\hline & 17.2 & \pm & 1.6 & 17.6 & \pm & 0.8 & 17.9 & \pm & 0.7 & 16.9 & \pm & 1.0 & 21.7 & \pm & 1.0 & 21.3 & \pm & 1.2 & 21.3 & \pm & 2.0 & 21.9 & \pm & 1.1 \\
\hline $\mathrm{Pb}$ & 503 & \pm & 47 & 478 & \pm & 50 & 515 & \pm & 26 & 537 & \pm & 19 & 1656 & \pm & 163 & 1573 & \pm & 154 & 1607 & \pm & 134 & 1748 & \pm & 92 \\
\hline $\mathrm{Zn}$ & 2459 & \pm & 326 & 2274 & \pm & 159 & 2221 & \pm & 161 & 2359 & \pm & 142 & 4651 & \pm & 553 & 4512 & \pm & 556 & 4162 & \pm & 555 & 4821 & \pm & 332 \\
\hline $\mathrm{Cu}$ & 45 & \pm & 1 & 45 & \pm & 3 & 46 & \pm & 2 & 45 & \pm & 1 & 108 & \pm & 9 & 105 & \pm & 9 & 102 & \pm & 9 & 116 & \pm & 5 \\
\hline $\mathrm{Mn}$ & 404 & \pm & 59 & 402 & \pm & 41 & 391 & \pm & 45 & 390 & \pm & 34 & 402 & \pm & 24 & 357 & \pm & 35 & 371 & \pm & 47 & 391 & \pm & 14 \\
\hline $\mathrm{Fe}$ & 36,565 & \pm & 3465 & 35,691 & \pm & 1036 & 32,824 & \pm & 3825 & 35,753 & \pm & 1772 & 32,124 & \pm & 1948 & 30,593 & \pm & 2131 & 29,694 & \pm & 2389 & 31,118 & \pm & 776 \\
\hline $\mathrm{Al}$ & 2464 & \pm & 297 & 2637 & \pm & 290 & 2746 & \pm & 471 & 2572 & \pm & 161 & 2205 & \pm & 280 & 2132 & \pm & 168 & 2133 & \pm & 491 & 2537 & \pm & 163 \\
\hline $\mathrm{Ca}$ & 7783 & \pm & 655 & 8403 & \pm & 1177 & 7988 & \pm & 1689 & 7226 & \pm & 1071 & 26,685 & \pm & 7165 & 26,440 & \pm & 3807 & 25,352 & \pm & 3776 & 26,492 & \pm & 3614 \\
\hline $\mathrm{Mg}$ & 1789 & \pm & 106 & 1767 & \pm & 119 & 1682 & \pm & 172 & 1568 & \pm & 204 & 3434 & \pm & 433 & 3332 & \pm & 339 & 3129 & \pm & 193 & 3269 & \pm & 145 \\
\hline $\mathrm{Na}$ & 363 & \pm & 48 & 356 & \pm & 16 & 292 & \pm & 14 & 390 & \pm & 110 & 382 & \pm & 62 & 373 & \pm & 65 & 317 & \pm & 49 & 390 & \pm & 27 \\
\hline K & 2184 & \pm & 100 & 2168 & \pm & 152 & 2127 & \pm & 149 & 2259 & \pm & 162 & 2293 & \pm & 145 & 2281 & \pm & 175 & 2106 & \pm & 145 & 2138 & \pm & 103 \\
\hline
\end{tabular}

$\mathrm{P}_{1}$ : calcium dihydrogen phosphate; $\mathrm{P}_{2}$ : calcium hydrogen phosphate; $\mathrm{P}_{3}$ : mixture of $\mathrm{P}_{1}$ and $\mathrm{P}_{2}$ (75/25).

Table 5. Concentration $\left(\mathrm{mg} \mathrm{kg}^{-1} ; n=5\right)$ of metal transition, alkali, and alkaline earth metals measured in the shoots of ryegrass, grown in unamended and amended soils G1 and G2.

\begin{tabular}{|c|c|c|c|c|c|c|c|c|c|c|c|c|c|c|c|c|c|c|c|c|c|c|c|c|}
\hline \multirow{2}{*}{$\frac{\text { Metal }}{\mathrm{Cd}}$} & \multicolumn{3}{|c|}{ Soil G1 } & \multicolumn{3}{|c|}{ Soil G1 $+P_{1}$} & \multicolumn{3}{|c|}{ Soil G1 $+P_{2}$} & \multicolumn{3}{|c|}{ Soil G1 $+\mathbf{P}_{3}$} & \multicolumn{3}{|c|}{ Soil G2 } & \multicolumn{3}{|c|}{ Soil G2 $+\mathbf{P}_{1}$} & \multicolumn{3}{|c|}{ Soil G2 $+P_{2}$} & \multicolumn{3}{|c|}{ Soil G2 $+\mathbf{P}_{3}$} \\
\hline & 11.0 & \pm & 0.1 & 7.1 & \pm & 0.3 & 7.7 & \pm & 0.9 & 9.0 & \pm & 0.2 & 3.3 & \pm & 0.0 & 3.6 & \pm & 0.1 & 3.5 & \pm & 0.7 & 2.8 & \pm & 0.1 \\
\hline $\mathrm{Pb}$ & 7.0 & \pm & 0.5 & 1.4 & \pm & 0.8 & 3.8 & \pm & 1.0 & 7.2 & \pm & 0.6 & 12.7 & \pm & 0.6 & 11.3 & \pm & 2.2 & 6.8 & \pm & 1.2 & 7.1 & \pm & 0.6 \\
\hline $\mathrm{Zn}$ & 737 & \pm & 5 & 566 & \pm & 28 & 587 & \pm & 11 & 624 & \pm & 10 & 273 & \pm & 2 & 295 & \pm & 13 & 297 & \pm & 16 & 271 & \pm & 3 \\
\hline $\mathrm{Cu}$ & 4.5 & \pm & 0.3 & 3.5 & \pm & 0.1 & 3.2 & \pm & 0.2 & 4.3 & \pm & 0.2 & 3.3 & \pm & 0.1 & 2.3 & \pm & 0.7 & 2.0 & \pm & 0.3 & 2.7 & \pm & 0.1 \\
\hline Mn & 164 & \pm & 1 & 167 & \pm & 12 & 144 & \pm & 19 & 199 & \pm & 3 & 60 & \pm & 0 & 53 & \pm & 6 & 74 & \pm & 9 & 41 & \pm & 0 \\
\hline $\mathrm{Fe}$ & 184 & \pm & 1 & 37 & \pm & 2 & 56 & \pm & 40 & 210 & \pm & 3 & 116 & \pm & 1 & 72 & \pm & 20 & 24 & \pm & 5 & 20 & \pm & 2 \\
\hline $\mathrm{Al}$ & 172 & \pm & 8 & 55 & \pm & 23 & 75 & \pm & 32 & 152 & \pm & 5 & 106 & \pm & 7 & 106 & \pm & 46 & 125 & \pm & 32 & 28 & \pm & 1 \\
\hline $\mathrm{Ca}$ & 13,390 & \pm & 354 & 10,466 & \pm & 1340 & 10,642 & \pm & 976 & 13,936 & \pm & 352 & 19,027 & \pm & 6 & 14,408 & \pm & 1128 & 17,919 & \pm & 398 & 14,656 & \pm & 278 \\
\hline $\mathrm{Mg}$ & 4416 & \pm & 18 & 3632 & \pm & 70 & 3761 & \pm & 357 & 4485 & \pm & 91 & 4162 & \pm & 24 & 3502 & \pm & 325 & 3903 & \pm & 379 & 3343 & \pm & 115 \\
\hline $\mathrm{Na}$ & 12,105 & \pm & 97 & 10306 & \pm & 188 & 12,114 & \pm & 1117 & 11,793 & \pm & 370 & 15,181 & \pm & 306 & 11,854 & \pm & 1009 & 13,907 & \pm & 2556 & 10,404 & \pm & 122 \\
\hline $\mathrm{K}$ & 24,533 & \pm & 129 & 23916 & \pm & 269 & 20,392 & \pm & 3871 & 24,430 & \pm & 523 & 16,625 & \pm & 68 & 17,315 & \pm & 457 & 16,832 & \pm & 1180 & 17,686 & \pm & 91 \\
\hline
\end{tabular}

$\mathrm{P}_{1}$ : calcium dihydrogen phosphate; $\mathrm{P}_{2}$ : calcium hydrogen phosphate; $\mathrm{P}_{3}$ : mixture of $\mathrm{P}_{1}$ and $\mathrm{P}_{2}(75 / 25)$. 
Although the concentration of alkali and alkaline earth metals were in the following orders $\mathrm{Ca}>\mathrm{K}>\mathrm{Mg}>\mathrm{Na}$ in $\mathrm{G} 1$ and $\mathrm{Ca}>\mathrm{Mg}>\mathrm{K}>\mathrm{Na}$ in G2 (Table 4), those in the shoots of ryegrass grown on soils G1 and amended soil G2 were $\mathrm{K}>\mathrm{Ca}>\mathrm{Na}>\mathrm{Mg}$, but $\mathrm{Ca}>\mathrm{K}>\mathrm{Na}>\mathrm{Mg}$ for ryegrass grown on the unamended soil G2. This result may be explained by the (i) decrease of Ca concentration in the shoots of ryegrass in presence of phosphates (up to $25 \%$; Table 5) and (ii) the high concentration of Ca in G2 (Table 4). The immobilization of Ca using phosphates has been also observed for ryegrass grown on G1 (except for the mixture of phosphates), and the same trends were highlighted for $\mathrm{Mg}$ and $\mathrm{Na}$. Note that the transfer of these cations from the soil to the ryegrass shoots was more limited using $P_{1}$ than $P_{2}$ and $P_{3}$. In contrast, the phosphates did not have effects on the availability of $K$ (Table 5). This is probably due to the fact that $\mathrm{K}$ is a primary nutrient and was defined as the most important element for plant nutrition [58,59]. Indeed, a minimum level of $\mathrm{K}$ in vacuole is necessary to maintain turgor and to avoid modifications of the metabolic processes and a decline in the growth of plants [60]. The ratio $\mathrm{K} /(\mathrm{Ca}+\mathrm{Mg})$ is commonly used to define the risk of contracting grass tetany by cattle and to compare the assimilation of monovalent and divalent cations by plants [61,62]. This ratio ranged from 1.32 to 1.87 for G1, reflecting a higher absorption of monovalent over divalent cations, and was in the range $0.71-1.00$ for G2, highlighting a higher absorption of divalent over monovalent cations. These ratio values help to understand why for each modality, the biomass of ryegrass grown on G1 and G2 was not statistically different. Except the pH, the organic matter, and the clay contents, everything suggests that the biomass of ryegrass is affected by the concentration of PTEs and the ratio $\mathrm{K} /(\mathrm{Ca}+\mathrm{Mg})$, both parameters having antagonist effects. The highest shoots biomass, obtained for the two soils amended with $\mathrm{P}_{1}$ (Figure 1) could so be explained by the lowest concentration of PTEs in the aerial parts and the highest ratio values $\left(1.71 \pm 0.15\right.$ for $\mathrm{G}_{1} \mathrm{P}_{1}$ and $0.97 \pm 0.07$ for $\left.\mathrm{G}_{2} \mathrm{P}_{1}\right)$.

\subsection{Concentrations of Transition, Alkali, and Alkaline Earth Metals And Aluminum in the Roots of Ryegrass}

The PTEs, alkali and alkaline earth metals concentrations are summarized in Table 6. The concentrations of $\mathrm{Cd}, \mathrm{Pb}, \mathrm{Fe}$, and $\mathrm{Ca}$ were significantly higher in the roots of ryegrass grown on the unamended soil G2 than those on the unamended soil G1. These results correlated well with the fact that the total concentrations of $\mathrm{Cd}, \mathrm{Pb}$, and $\mathrm{Ca}$ were higher in $\mathrm{G} 2$ than in $\mathrm{G} 1$. These trends were also observed for soils amended with $\mathrm{P}_{1}, \mathrm{P}_{2}$, or $\mathrm{P}_{3}$, since the most substantial increase of the concentration of $\mathrm{Cd}, \mathrm{Pb}, \mathrm{Fe}$, and $\mathrm{Ca}$ by phosphates occurred in $\mathrm{G} 2$. The major effect was highlighted in $\mathrm{G} 2$ amended with $\mathrm{P}_{2}$, since the concentrations of $\mathrm{Cd}, \mathrm{Pb}, \mathrm{Fe}$, and $\mathrm{Ca}$ were up to $55.4 \mathrm{mg} \mathrm{kg}^{-1}$, $238 \mathrm{mg} \mathrm{kg}^{-1}, 2657 \mathrm{mg} \mathrm{kg}^{-1}$, and $4579 \mathrm{mg} \mathrm{kg}^{-1}$, respectively. Although the concentrations of $\mathrm{Zn}, \mathrm{Cu}$, and $\mathrm{Mg}$ were the highest in G2, their concentrations in the roots of ryegrass from G1 were higher than those from G2 (Table 6). The same trends were obtained after phosphates, except for $\mathrm{Cu}$, even if its concentration remained at low level (from 20.4 to $38.5 \mathrm{mg} \mathrm{kg}^{-1}$ and from 13.2 to $38.9 \mathrm{mg} \mathrm{kg}^{-1}$ in amended soils $\mathrm{G} 2$ and $\mathrm{G} 1$, respectively). As it was observed for $\mathrm{Cd}, \mathrm{Pb}, \mathrm{Fe}$, and $\mathrm{Ca}$, the accumulation of $\mathrm{Zn}, \mathrm{Cu}$, and $\mathrm{Mg}$ was favored in amended soils G1 and G2 after amendment using $\mathrm{P}_{2}$. No significant differences between the concentrations of $\mathrm{Al}, \mathrm{Na}$, and $\mathrm{K}$ in soils $\mathrm{G} 1$ and $\mathrm{G} 2$ and in roots of ryegrass from both soils were highlighted (Table 6). Depending on phosphates and soils, significant increases of $\mathrm{Al}, \mathrm{Na}$, and $\mathrm{K}$ concentrations in the roots of ryegrass were observed, especially for amended soils $\mathrm{G} 1$ and G2 (except K) using $\mathrm{P}_{2}$.

It is well known that the bioavailability of metals depends on the radius, the ionic charge, and the first hydrolysis constant of metals [63-65]. In addition, the speciation of metals can be modified by the development of the physicochemical and biological processes (metal uptake, accumulation, sequestration, and metabolization) around the plant's rhizosphere [66,67]. The variation in $\mathrm{pH}$ and organic carbon in the topsoil is due to the release of organic compounds from the plants and microbial activities. Among these organic compounds, flavonoids, lipids, sugars, amino acids, and LMWOAs such as acetic, citric, oxalic, propionic, butyric, malic, fumaric, malonic, and succinic acids have been widely found in the plant's rhizosphere [68-70]. These organic compounds react with metals to form complexes, which are adsorbed by the roots and then translocated into the aboveground parts of plants, 
and have been recently used as environmental friendly remediation of contaminated soils [71,72]. For a better understanding of our results, chemical extraction was firstly performed on unamended and amended soils with a mixture of organic acids and then, the metal phytoavailability was studied using three indicators.

\subsection{Evaluation of the Phytoavailability Using a Mixture of Organic Acids}

Acetic and citric acids are the two main root exudates that have been widely used to assess the bioavailability of metals [73-75]. Their chemical actions on the soil solid phases are the solubilization of PTEs, resulting from the dissolution of carbonates/Fe oxides/hydroxides and the complexation of PTEs. Indeed, they were used to simulate the complexing behavior of the root exudates [39,76,77]. These acids were used in mixture with others like lactic, malic, and formic acids, and the resulting solution, currently called low-molecular-weight organic acids mixture, was described as a robust approach in different context to evaluate the bioavailability of PTEs in acidic, neutral, and slightly alkaline soils $[39,78,79]$. In this condition, the extractable metal may be associated to the short-term available pool of PTEs $[80,81]$. Whatever the conditions, the extractable PTEs concentrations in G1 were in the following decreasing order $\mathrm{Zn}>\mathrm{Fe}>\mathrm{Al}>\mathrm{Mn}>\mathrm{Cd}>\mathrm{Pb}>\mathrm{Cu}$, whereas in unamended and amended soils $\mathrm{G} 2$, the order was $\mathrm{Fe}>\mathrm{Zn}>\mathrm{Al}>\mathrm{Mn}>\mathrm{Cd}>\mathrm{Pb}>\mathrm{Cu}$ (Table 7). As shown in the previous section, the total concentrations of PTEs in both G1 and G2 soils were ordered in the following sequence $\mathrm{Fe}>\mathrm{Zn}>\mathrm{Al}>\mathrm{Pb}>\mathrm{Mn}>\mathrm{Cu}>\mathrm{Cd}$. This result demonstrates that the extractable metal was not only dependent on the total PTE concentrations, but also on their affinity with soil substrates (organic and mineral) to form stable chemical compounds. Moreover, note that the concentrations of extractable $\mathrm{Cd}, \mathrm{Cu}, \mathrm{Mn}$, and $\mathrm{Zn}$ were the highest in unamended and amended soil G1. Once again, this result confirms there is no evident relation between extractable and total PTEs concentrations, since the total concentrations of these PTEs were the highest in soil G2.

Interesting findings were the relation between the total PTEs concentrations, their concentrations in the (i) LMWOAs extracting solutions, (ii) shoots of ryegrass, and (iii) root of ryegrass. Indeed, concentrations of major pollutants $(\mathrm{Cd}, \mathrm{Pb}, \mathrm{Zn}$, and $\mathrm{Cu})$, resulting mainly from the emission of dusts in the operating period of the $\mathrm{Pb}$ and $\mathrm{Zn}$ smelters, were highest in the roots of ryegrass grown on the most contaminated soil G2. The highest concentrations in the shoots of ryegrass were obtained from soil G1, in which the extractable PTEs concentrations were the highest. Acquisition of information about the chemical availability of PTEs before biomass production is so crucial. This becomes all the more important when optimizing a phytomanagement technique with the aim at (i) producing foodstuff and feedstuff, (ii) creating added value, like the production of biosourced catalysts to synthesize molecules of interest [82-85], and (iii) recovering Cd, Zn, and Ni used in many industrial applications [85-87]. 
Table 6. Concentration $\left(\mathrm{mg} \mathrm{kg}^{-1} ; n=5\right)$ of metal transition, alkali, and alkaline earth metals measured in the roots of ryegrass, grown in unamended and amended soils G1 and G2.

\begin{tabular}{|c|c|c|c|c|c|c|c|c|c|c|c|c|c|c|c|c|c|c|c|c|c|c|c|c|}
\hline \multirow{2}{*}{$\frac{\text { Metal }}{\mathrm{Cd}}$} & \multicolumn{3}{|c|}{ Soil G1 } & \multicolumn{3}{|c|}{ Soil G1 + $P_{1}$} & \multicolumn{3}{|c|}{ Soil G1 + $P_{2}$} & \multicolumn{3}{|c|}{ Soil G1 + $P_{3}$} & \multicolumn{3}{|c|}{ Soil G2 } & \multicolumn{3}{|c|}{ Soil G2 $+P_{1}$} & \multicolumn{3}{|c|}{ Soil G2 $+\mathrm{P}_{2}$} & \multicolumn{3}{|c|}{ Soil G2 $+P_{3}$} \\
\hline & 19.7 & \pm & 0.9 & 19.2 & \pm & 1.9 & 25.0 & \pm & 3.4 & 21.1 & \pm & 2.2 & 43.7 & \pm & 6.3 & 51.0 & \pm & 10.7 & 55.4 & \pm & 6.1 & 49.6 & \pm & 4.6 \\
\hline $\mathrm{Pb}$ & 33.9 & \pm & 4.2 & 32.4 & \pm & 5.6 & 34.3 & \pm & 1.6 & 33.9 & \pm & 4.6 & 122.4 & \pm & 26.9 & 222.8 & \pm & 46.7 & 240.1 & \pm & 15.1 & 200.7 & \pm & 50.2 \\
\hline $\mathrm{Zn}$ & 1610 & \pm & 157 & 1409 & \pm & 207 & 1973 & \pm & 640 & 1545 & \pm & 148 & 954 & \pm & 24 & 1105 & \pm & 316 & 1366 & \pm & 78 & 1009 & \pm & 155 \\
\hline $\mathrm{Cu}$ & 23.4 & \pm & 3.1 & 25.8 & \pm & 7.4 & 19.1 & \pm & 4.6 & 19.0 & \pm & 4.3 & 21.7 & \pm & 2.0 & 34.9 & \pm & 2.1 & 29.4 & \pm & 3.9 & 26.9 & \pm & 5.0 \\
\hline $\mathrm{Mn}$ & 104 & \pm & 6 & 118 & \pm & 30 & 117 & \pm & 9 & 146 & \pm & 44 & 70 & \pm & 13 & 71 & \pm & 6 & 105 & \pm & 21 & 72 & \pm & 6 \\
\hline $\mathrm{Fe}$ & 1114 & \pm & 190 & 1100 & \pm & 167 & 1267 & \pm & 138 & 1234 & \pm & 248 & 2302 & \pm & 137 & 2541 & \pm & 170 & 2657 & \pm & 47 & 2506 & \pm & 180 \\
\hline $\mathrm{Al}$ & 185 & \pm & 51 & 234 & \pm & 81 & 281 & \pm & 60 & 232 & \pm & 75 & 213 & \pm & 52 & 320 & \pm & 64 & 381 & \pm & 58 & 300 & \pm & 76 \\
\hline $\mathrm{Ca}$ & 2666 & \pm & 71 & 2676 & \pm & 440 & 3664 & \pm & 782 & 2761 & \pm & 318 & 3633 & \pm & 368 & 4129 & \pm & 650 & 4579 & \pm & 421 & 4481 & \pm & 660 \\
\hline $\mathrm{Mg}$ & 954 & \pm & 27 & 833 & \pm & 120 & 1179 & \pm & 207 & 936 & \pm & 75 & 980 & \pm & 48 & 947 & \pm & 250 & 1033 & \pm & 58 & 915 & \pm & 57 \\
\hline $\mathrm{Na}$ & 5220 & \pm & 743 & 4688 & \pm & 888 & 6340 & \pm & 863 & 4724 & \pm & 660 & 4630 & \pm & 388 & 3582 & \pm & 569 & 6221 & \pm & 337 & 5415 & \pm & 1458 \\
\hline K & 7317 & \pm & 637 & 8011 & \pm & 1354 & 10,303 & \pm & 2290 & 8239 & \pm & 1143 & 8992 & \pm & 1207 & 7647 & \pm & 1073 & 7672 & \pm & 807 & 7778 & \pm & 1187 \\
\hline
\end{tabular}

$\mathrm{P}_{1}$ : calcium dihydrogen phosphate; $\mathrm{P}_{2}$ : calcium hydrogen phosphate; $\mathrm{P}_{3}$ : mixture of $\mathrm{P}_{1}$ and $\mathrm{P}_{2}(75 / 25)$.

Table 7. Extractable concentration of metal transition, alkali, and alkali earth metals $\left(\mathrm{mg} \mathrm{kg}^{-1} ; n=5\right)$ using low-molecular-weight organic acids in mixture.

\begin{tabular}{|c|c|c|c|c|c|c|c|c|c|c|c|c|c|c|c|c|c|c|c|c|c|c|c|c|}
\hline \multirow{2}{*}{$\begin{array}{l}\text { Metal } \\
\mathrm{Cd}\end{array}$} & \multicolumn{3}{|c|}{ Soil G1 } & \multicolumn{3}{|c|}{ Soil G1 + $\mathbf{P}_{1}$} & \multicolumn{3}{|c|}{ Soil G1 + $P_{2}$} & \multicolumn{3}{|c|}{ Soil G1 + $P_{3}$} & \multicolumn{3}{|c|}{ Soil G2 } & \multicolumn{3}{|c|}{ Soil G2 + $P_{1}$} & \multicolumn{3}{|c|}{ Soil G2 $+\mathrm{P}_{2}$} & \multicolumn{3}{|c|}{ Soil $G 2+P_{3}$} \\
\hline & 1.6 & \pm & 0.0 & 1.5 & \pm & 0.1 & 1.6 & \pm & 0.1 & 1.6 & \pm & 0.0 & 0.2 & \pm & 0.0 & 0.2 & \pm & 0.1 & 0.2 & \pm & 0.0 & 0.2 & \pm & 0.0 \\
\hline $\mathrm{Pb}$ & 1.3 & \pm & 0.1 & 1.3 & \pm & 0.1 & 1.3 & \pm & 0.1 & 1.4 & \pm & 0.1 & 2.2 & \pm & 0.1 & 2.2 & \pm & 0.1 & 2.1 & \pm & 0.1 & 2.2 & \pm & 0.2 \\
\hline $\mathrm{Zn}$ & 319 & \pm & 5 & 291 & \pm & 34 & 288 & \pm & 45 & 328 & \pm & 12 & 65 & \pm & 27 & 59 & \pm & 19 & 59 & \pm & 15 & 61 & \pm & 2 \\
\hline $\mathrm{Cu}$ & 0.8 & \pm & 0.1 & 0.8 & \pm & 0.1 & 0.8 & \pm & 0.1 & 0.8 & \pm & 0.0 & 0.5 & \pm & 0.0 & 0.6 & \pm & 0.2 & 0.5 & \pm & 0.0 & 0.5 & \pm & 0.0 \\
\hline Mn & 26 & \pm & 1 & 27 & \pm & 8 & 24 & \pm & 4 & 26 & \pm & 2 & 22 & \pm & 1 & 22 & \pm & 1 & 21 & \pm & 2 & 22 & \pm & 1 \\
\hline $\mathrm{Fe}$ & 115 & \pm & 9 & 117 & \pm & 27 & 113 & \pm & 17 & 108 & \pm & 2 & 142 & \pm & 13 & 153 & \pm & 24 & 131 & \pm & 24 & 142 & \pm & 23 \\
\hline $\mathrm{Ca}$ & 135 & \pm & 27 & 153 & \pm & 20 & 158 & \pm & 23 & 152 & \pm & 11 & 214 & \pm & 13 & 199 & \pm & 14 & 218 & \pm & 28 & 198 & \pm & 10 \\
\hline $\mathrm{Mg}$ & 82 & \pm & 5 & 85 & \pm & 6 & 80 & \pm & 6 & 79 & \pm & 1 & 121 & \pm & 7 & 121 & \pm & 7 & 125 & \pm & 4 & 124 & \pm & 4 \\
\hline $\mathrm{Na}$ & 170 & \pm & 3 & 156 & \pm & 17 & 165 & \pm & 26 & 172 & \pm & 1 & 25 & \pm & 2 & 28 & \pm & 4 & 24 & \pm & 2 & 24 & \pm & 1 \\
\hline $\mathrm{K}$ & 364 & \pm & 9 & 363 & \pm & 8 & 372 & \pm & 7 & 375 & \pm & 3 & 256 & \pm & 9 & 259 & \pm & 4 & 256 & \pm & 5 & 251 & \pm & 6 \\
\hline
\end{tabular}

$\mathrm{P}_{1}$ : calcium dihydrogen phosphate; $\mathrm{P}_{2}$ : calcium hydrogen phosphate; $\mathrm{P}_{3}$ : mixture of $\mathrm{P}_{1}$ and $\mathrm{P}_{2}(75 / 25)$. 
Extractable concentrations of alkali ( $\mathrm{K}$ and $\mathrm{Na}$ ) and alkaline earth $(\mathrm{Ca}$ and $\mathrm{Mg}$ ) metals correlated well with those measured in the roots of ryegrass from $\mathrm{G} 1(\mathrm{~K}>\mathrm{Na}>\mathrm{Ca}>\mathrm{Mg})$. This was not the case for roots of ryegrass from soil $\mathrm{G} 2(\mathrm{~K}>\mathrm{Ca}>\mathrm{Mg}>\mathrm{Na})$ due to the low extractable concentration of $\mathrm{Na}$ (from 22 to $31 \mathrm{mg} \mathrm{kg}^{-1}$; Table 7), a nonessential element for plants [88]. The concentration order of $\mathrm{K}, \mathrm{Ca}$, and $\mathrm{Mg}$ correlated well with the theory. Indeed, roots of plants are able to mobilize the nonexchangeable $\mathrm{K}$ from clays to avoid its depletion [89,90]. Although $\mathrm{Ca}$ and $\mathrm{Mg}$ are both divalent cations, their extractable concentrations were lower than that of $\mathrm{K}$. This result is somewhat at odds with the theory, since the stability constant reflects a best stability of the complex resulting from the reaction between divalent cations with LMWOAs. However, it is well known that extractable concentration of cations also depends on their total concentration. It is worth mentioning the different orders between alkali and alkaline earth metals in the shoots of ryegrass and those measured in LMWOAs extracting solutions. This finding confirmed that artificial chemical solutions cannot (i) mimic the biological and physiological process and (ii) take into consideration the dynamic of the transformation in the rhizosphere environment. For instance, root exudates, like LMWOAs, are able to react with cations in order to produce soluble organometallic complexes in the microenvironment of the rhizosphere, particularly when these cations are nutrients [68,91,92]. Therefore, the phytoavailabillity of PTEs, alkali and alkali earth metals was studied using three mathematical indicators: uptake ability (BCF), real phytoavailability, and transfer (TF) for a better understanding.

\subsection{Phytoavailability of PTEs, Alkali and Alkaline Earth Metals in Unamended and Amended Soils}

The set of data related to the three indicators of the phytoavailability is presented in Figure 2. The first ratio used to evaluate the effects of phosphates on the phytoavailability of PTEs, alkali and alkaline earth metals was the plant/substrate ratio. This ratio is usually used to assess the plant's ability to uptake metals. It was calculated considering metals in the plant parts (roots and shoots) and the concentration of metals in the soil on which the ryegrass grow. As shown in Figure 2, this indicator, commonly named bioconcentration factor (BCF; [34]) differed according to the metals and the soils. The $\mathrm{BCF}$ values of monovalent cations ( $\mathrm{Na}$ and $\mathrm{K}$ ) were the highest, ranging from 35.7 to 80.4 and from 10.1 to 16.7 for $\mathrm{Na}$ and $\mathrm{K}$, respectively. For alkaline earth metals ( $\mathrm{Ca}$ and $\mathrm{Mg}$ ), the $\mathrm{BCF}$ values were in the range 1.8-3.0 for $\mathrm{Ca}$ and 2.3-4.5 for $\mathrm{Mg}$ on unamended and amended soils G1, whereas they were reduced by half on the unamended and amended soils G2. Note that BCF values of $\mathrm{Ca}$ and $\mathrm{Mg}$ were slightly the lowest in presence of $P_{1}$. This trend was also observed for $\mathrm{Cd}$ and correlated well with the fact that competition between $\mathrm{Ca}$ and $\mathrm{Cd}$ may exist since the ionic radius of $\mathrm{Cd}^{2+}(0.097 \mathrm{~nm})$ is very close to that of $\mathrm{Ca}^{2+}(0.094 \mathrm{~nm})$ and the valence of both cations is the same. The physicochemical characteristics of $\mathrm{Cd}$ and $\mathrm{Ca}$ ions can contribute to explain the highest $\mathrm{BCF}$ value for $\mathrm{Cd}$ among the studied PTEs, the BCF order being $\mathrm{Cd}>\mathrm{Zn}>\mathrm{Mn}>\mathrm{Cu}>\mathrm{Al}>\mathrm{Pb}>\mathrm{Fe}$ (Figure 2). This order highlights the high phytoavailability of $C d$ in the soil studied, the BCF value being in the range 1.7-3.4. This result is consistent with the fact that $\mathrm{Cd}$ ions move through the plant tissues using Ca channels by active transport, since Ca ion is an essential nutrient for plants [93].

Some studies reported interesting discussions about the potential utilization of plants for phytoextraction or phytostabilizatation [41]. According to Yoon et al. [94], BCF and TF (translocation factor) may be used to establish if a plant is a good candidate or not for phytoremediation purposes. When $\mathrm{BCF}$ and TF are greater than one, plants have the potential to be used for phytoextraction; when $\mathrm{BCF}$ is higher and TF is less than one, the plant is defined as a metal-tolerant plant; when BCF and TF are less than one, plants have the potential to be used for phytostabilization. In view of the TF values, the second ratio studied in the current study, three evident metal groups may be established. The first is composed of $\mathrm{Cd}, \mathrm{Cu}, \mathrm{Fe}, \mathrm{Pb}$, and $\mathrm{Zn}$, for which TF was below 1, the second was formed by alkali and alkaline earth metals for which TF was higher than one, and in the third group, $\mathrm{Al}$ and $\mathrm{Mn}$, for which the BCF values depended on the soil studied and the modality. For instance, the BCF values for $\mathrm{Mn}$ were higher than one for ryegrass grown in unamended and amended soil G1, whereas they were below one for ryegrass grown on unamended and amended soil G2. In contrast, $P_{1}$ and $P_{2}$ slowed 
down the ability of ryegrass to uptake $\mathrm{Al}$ in soil $\mathrm{G} 1$ ( $\mathrm{BCF}<1$ ), whereas $\mathrm{BCF}$ values were less than one in unamended and amended soil G2. There is so no doubt on the ryegrass capabilities of extracting $\mathrm{Na}$ and K, which may improve the aggregation of soil particles over the long-term. On the other hand, as regards the $\mathrm{BCF}$ and TF values and under the experimental conditions, ryegrass may be defined as a metal-tolerant plant that can be used for phytostabilization. This point ties up the findings of many authors that selected ryegrass as a suitable plant for the revegetation of contaminated soils from metallurgical sites [1], able to remove Cd from soils [95].
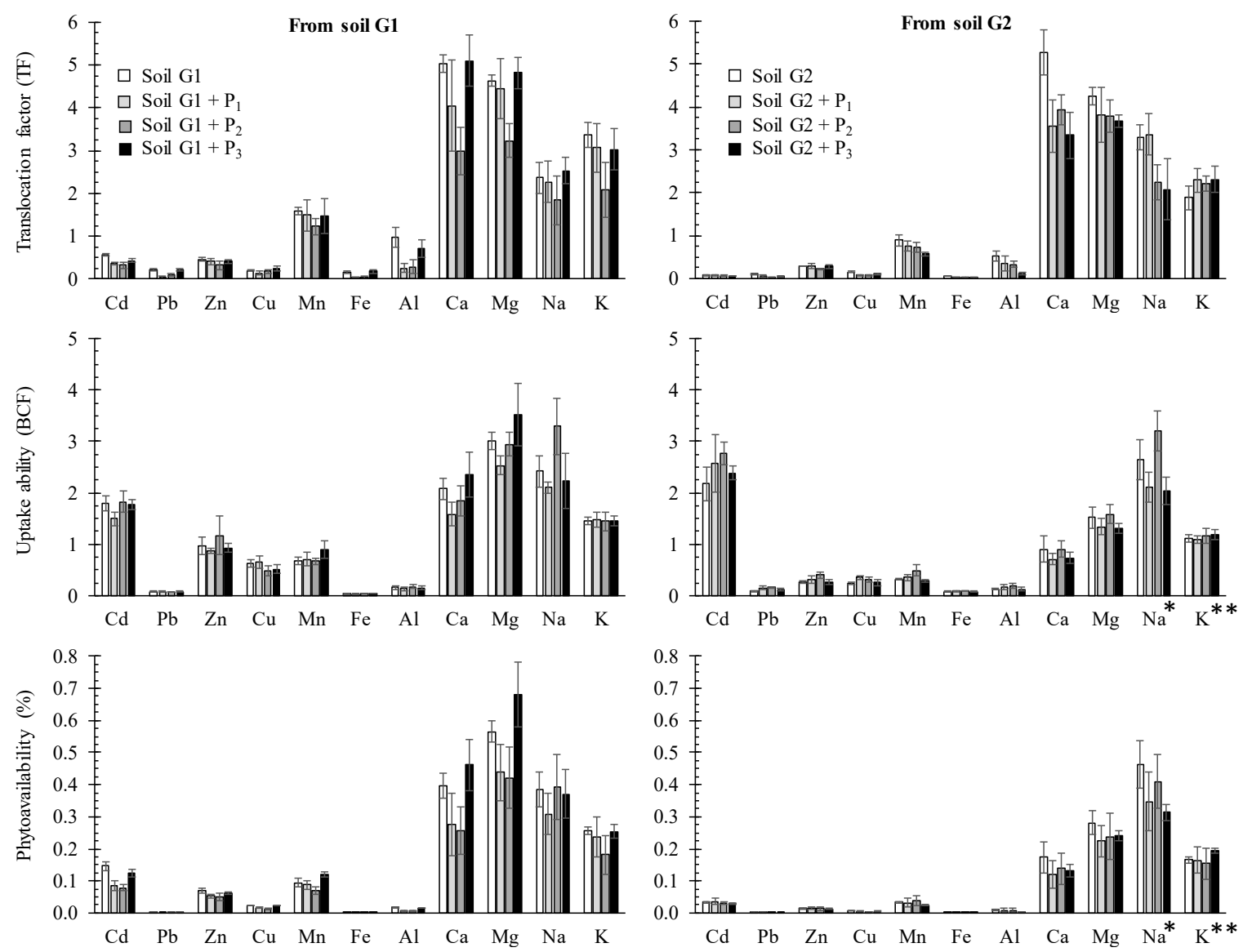

Figure 2. Translocation factors, uptake ability, and phytoavailability of PTEs, alkali, and alkaline earth metals (mean \pm standard deviation; $n=5$ ).

The third ratio was related to the real phytoavailability of PTEs, alkali, and alkaline earth metals and takes into account the concentration of metals in plant and soil, the above-ground biomass, and the soil mass. As shown in Figure 2, the real phytoavailability was higher in the less contaminated soil G1 than in soil G2. This result correlated well with the extractable metal concentration measured in the LMWOAs solution for $\mathrm{Cd}, \mathrm{Zn}, \mathrm{Ca}, \mathrm{Mn}, \mathrm{Na}$, and $\mathrm{K}$. Recently, similarities between the real phytoavailability of $\mathrm{Pb}, \mathrm{Cu}$, and $\mathrm{Zn}$ and their water extractability have been found [42]. The real phytoavailability order was $\mathrm{Na}>\mathrm{K}>\mathrm{Mg}>\mathrm{Ca}>\mathrm{Cd}>\mathrm{Mn}>\mathrm{Zn}>\mathrm{Cu}>\mathrm{Al}>\mathrm{Pb}>\mathrm{Fe}$. The main effects of phosphates on the real phytoavailability of PTEs, alkali, and alkaline earth metals were obtained using DCP on soil G1, in which the availability of metals were the highest. With this amendment, the phytoavailability of $\mathrm{Cd}, \mathrm{Pb}, \mathrm{Cu}$, and $\mathrm{Al}$ was reduced by $27 \%-57 \%, 64.2 \%-94.8 \%, 18.3 \%-43.1 \%$, and $50.1 \%-89.4 \%$, respectively. Interestingly, the real phytoavailability of Zn was higher in soil G1 than in soil G2 for all modalities. This result is consistent with the findings of Sarret et al. [96]. The authors highlighted the highest lability of $\mathrm{Zn}$ in soil located around the Auby's smelter (Nyrstar) in comparison with those around the former smelter Metaleurop Nord. In a same way, we can assume that the lability of $\mathrm{Cd}, \mathrm{Cu}, \mathrm{Mn}, \mathrm{Ca}, \mathrm{Mg}, \mathrm{Na}$, and $\mathrm{K}$ is the highest in the soils located in the surrounding of 
the Nyrstar smelter. Recent studies demonstrated the importance of the isotopic signature in the phytoavailability of few metals like $\mathrm{Pb}, \mathrm{Cu}, \mathrm{Zn}$, and $\mathrm{Mg}[97,98]$. According to the authors, heavy $\mathrm{Zn}$ isotopes are mainly present in the roots, whereas light $\mathrm{Zn}$ isotopes are transferred in the aerial parts. Consequently, the difference in the isotopic fractionation of $\mathrm{Zn}$ in the soils around the former smelter Metaleurop Nord and Nystar could explain the difference between the TF values of $\mathrm{Zn}$ in ryegrass grown on G1 and G2 [97]. Further studies are so necessary to define the isotopic fractionation of PTEs like $\mathrm{Cd}, \mathrm{Pb}, \mathrm{Cu}$, and $\mathrm{Al}$ around these two $\mathrm{Pb}$ and $\mathrm{Zn}$ smelters for a better understanding of the PTEs transfer from the soil to the different plant tissues.

\subsection{Potential Application of the Aerial Parts of Ryegrass}

Based on recent studies described by Hechelski et al. [82], the aerial parts of ryegrass may have potential interest in organic chemistry and polymer science. Indeed, recent studies reported the use of metals from hyperaccumulating plants biomass to produce ecocatalysts. Among them, $\mathrm{Al}, \mathrm{Cu}, \mathrm{Fe}, \mathrm{Mn}$, and $\mathrm{Zn}$ are of great interest since they were transformed into Lewis acids (LA), an important class of catalysts used in many organic transformations [82-85]. It is well accepted that the metal concentration in the aerial parts of plants has to be higher than $1000 \mathrm{mg} \mathrm{kg}^{-1} \mathrm{DW}$ (Dry Weight) for the conception of ecocatalysts $[99,100]$. In view of the results described in Table 5, the aerial parts of ryegrass should be interesting for this application, the concentration of potential $\mathrm{LA}(\mathrm{Al}, \mathrm{Cu}, \mathrm{Fe}, \mathrm{Mn}$, and $\mathrm{Zn})$ ranging from 792 to $1280 \mathrm{mg} \mathrm{kg}^{-1} \mathrm{DW}$. However, the presence of $\mathrm{Cd}$ and $\mathrm{Pb}$ in the plant biomass may pose a problem for human health since both metal are defined as carcinogenic, mutagenic, and reprotoxic substances. It is worth noting that in the present study, $\mathrm{Cd}$ and $\mathrm{Pb}$ were in small amounts in the plant biomass in comparison with potential LA, the ratios LA/Cd ranging from 104 to 193, and $\mathrm{LA} / \mathrm{Pb}$ being in the range 41-1534.

\section{Conclusions}

Calcium dihydrogen phosphate $\left(\mathrm{Ca}\left(\mathrm{H}_{2} \mathrm{PO}_{4}\right)_{2}\right)$, calcium hydrogen phosphate $\left(\mathrm{CaHPO}_{4}\right)$, and a mixture of both phosphates were added in sustainable amounts to contaminated garden soils in order to drop the carcinogenic, mutagenic, and reprotoxic metals (e.g., $\mathrm{Cd}, \mathrm{Pb}$ ) and to rise up the transfer of nutrients. Despite the concentration of PTEs ( $\mathrm{Al}, \mathrm{Cd}, \mathrm{Cu}, \mathrm{Mn}, \mathrm{Pb}$, and $\mathrm{Zn}$ ) in soils (up to $10.03 \mathrm{~g} \mathrm{~kg}^{-1}$ ), no visual toxicity symptoms was recorded, making this plant suitable for the revegetation of contaminated gardens. The concentrations of PTEs in the ryegrass shoots were not dependent on their concentrations in soils, suggesting a relation between the phytoavailability of PTEs and their stability in soils, mainly explained by the organic matter and clay contents. In contrast, the concentrations of metals in the roots of ryegrass depended on the concentrations of metals in soils and increased in amended soils.

The shoot biomass of ryegrass significantly increased with the application of $\mathrm{Ca}\left(\mathrm{H}_{2} \mathrm{PO}_{4}\right)_{2}$, a negative effect was highlighted using $\mathrm{CaHPO}_{4}$, whereas no effect on the biomass was observed using the mixture of phosphates. Among the three studied amendments, $\mathrm{Ca}\left(\mathrm{H}_{2} \mathrm{PO}_{4}\right)_{2}$ was the most appropriate to our objectives: (i) limitation of the concentration of $\mathrm{Cd}$ and $\mathrm{Pb}$ in the ryegrass shoots, especially from soil G1, (ii) ability to maintain the transfer of macro- and micronutrients, (iii) limitation of the availability of PTEs in soil where they were the highest, (iv) improving the ratio values between potential Lewis acids and $\mathrm{Cd}$ or $\mathrm{Pb}$, in order to use transformed shoot biomass of ryegrass as biosourced catalysts. This is the main objective of the second part of the current study.

Author Contributions: Formal analysis, Investigation, Methodology, Writing—original draft and editing, C.W.; Writing-review, M.H.

Funding: This research was funded by YNCREA Hauts-de-France-ISA.

Conflicts of Interest: The authors declare no conflict of interest. 


\section{References}

1. Arienzo, M.; Adamo, P.; Cozzolino, V. The potential of Lolium perenne for revegetation of contaminated soil from a metallurgical site. Sci. Total Environ. 2004, 319, 13-25. [CrossRef]

2. Peng, F.; Li, S.; Xiao-Hui, S.; Ru-Lai, L.; Cheng, J.; Hai-Yan, Z.; Zeng-Jie, L.; Zhi-Min, L.; Wei, G.; $\mathrm{Xu}$-Dong, H.; et al. Response and accumulation ability of perennial ryegrass to plumbum and cadmium stress. Fresenius Environ. Bull. 2017, 26, 598-606.

3. Salama, A.K.; Osman, K.A.; Gouda, N.A.R. Remediation of lead and cadmium-contaminated soils. Int. J. Phyt. 2016, 18, 364-367. [CrossRef] [PubMed]

4. Gunawardana, B.; Singhal, N.; Johnson, A. Amendments and their combined application for enhanced copper, cadmium, lead uptake by Lolium perenne. Plant Soil 2010, 329, 283-294. [CrossRef]

5. Zhao, H.Y.; Lin, L.J.; Yan, Q.L.; Yang, Y.X.; Zhu, X.M.; Shao, J.R. Effects of EDTA and DTPA on lead and zinc accumulation of ryegrass. J. Environ. Prot. 2011, 2, 932-939. [CrossRef]

6. Kamari, A.; Pulford, I.D.; Hargreaves, J.S.J. Metal accumulation in Lolium perenne and Brassica napus as affected by application of chitosans. Int. J. Phyt. 2012, 14, 894-907. [CrossRef] [PubMed]

7. Cao, S.; Wang, W.; Zhao, Y.; Yang, S.; Wang, F.; Zhang, J.; Yongchang, S. Enhancement of lead phytoremediation by perennial ryegrass (Lolium perenne L.) using agent of Streptomyces pactum Act 12. J. Pet. Environ. Biotechnol. 2016, 7, 269. [CrossRef]

8. Liang, S.X.; Jin, Y.; Liu, W.; Li, X.; Shen, S.G.; Ding, L. Feasibility of Pb phytoextraction using nano-materials assisted ryegrass: Results of a one-tear field-scale experiment. J. Environ. Manag. 2017, 190, 170-175. [CrossRef]

9. Black, A.; McLaren, R.G.; Reichman, S.M.; Speir, T.W.; Condron, L.M.; Houliston, G. Metal bioavailability dynamics during a two-year trial using ryegrass (Lolium perenne L.) grown in soils treated with biosolids and metal salts. Soil Res. 2012, 50, 304-311. [CrossRef]

10. Afegbua, S.L.; Batty, L.C. Effect of single and mixed polycyclic aromatic hydrocarbon contamination on plant biomass yield and PAH dissipation during phytoremediation. Environ. Sci. Pollut. Res. 2018, 25, 18596-18603. [CrossRef]

11. Radziemska, M.; Bilgin, A.; Vaverková, M.D. Application of mineral-based amendments for enhancing phytostabilization in Lolium perenne L. cultivation. Clean Soil Air Water 2018, 46, 1-10. [CrossRef]

12. Burges, A.; Alkorta, I.; Epelde, L.; Garbisu, C. From phytoremediation of soil contaminants to phytomanagement of ecosystem services in metal contaminated sites. Int. J. Phyt. 2018, 20, 384-397. [CrossRef] [PubMed]

13. Xie, H.; Zhu, L.; Wang, J. Combined treatment of contaminated soil with a bacterial Stenotrophomonas strain DXZ9 and ryegrass (Lolium perenne) enhances DDT and DDE remediation. Environ. Sci. Pollut. Res. 2018, 25, 31895-31905. [CrossRef] [PubMed]

14. Selvi, A.; Rajasekar, A.; Theerthagiri, J.; Ananthaselvam, A.; Sathishkumar, K.; Madhavan, J.; Rahman, P.K.S.M. Integrated remediation processes toward heavy metal removal/recovery from various environments-A review. Front. Environ. Sci. 2019, 7, 1-15. [CrossRef]

15. Han, S.; Li, X.; Amombo, E.; Fu, J.; Xie, Y. Cadmium tolerance of perennial ryegrass induced by Aspergillus aculeatus. Front Microbiol. 2018, 9, 1-13. [CrossRef]

16. Wang, K.; Huang, H.; Zhu, Z.; Li, T.; He, Z.; Yang, X.; Alva, A. Phytoextraction of metals and rhizoremediation of PAHs in co-contaminated (Lolium perenne) or cator (Rininus Communis). Int. J. Phyt. 2013, 15, $283-298$. [CrossRef]

17. Liu, Y.; Ma, L.Y.; Lu, Y.C.; Jiang, S.S.; Wu, H.J.; Yang, H. Comprehensive analysis of degradation and accumulation of ametryn in soils and in wheat, maize, ryegrass and alfalfa plants. Ecotoxicol. Environ. Saf. 2017, 140, 264-270. [CrossRef]

18. Pruvot, C.; Douay, F.; Fourrier, H.; Waterlot, C. Heavy metals in soil, crops and grass as a source of human exposure in the former mining areas. J. Soils Sediments 2006, 6, 215-220. [CrossRef]

19. Douay, F.; Roussel, H.; Pruvot, C.; Waterlot, C. Impact of a smelter closedown on metal contents of wheat cultivated in the neighbourhood. Environ. Sci. Pollut. Res. 2008, 15, 162-169. [CrossRef]

20. Augustsson, A.; Uddh-Söderberg, T.; Filipsson, M.; Helmfrid, I.; Berglund, M.; Karlsson, H.; Hogmalm, J.; Karlsson, A.; Alriksson, S. Challenges in assessing the health risks of consuming vegetables in metal-contaminated environments. Environ. Int. 2018, 113, 269-280. [CrossRef] 
21. Osborne, L.R.; Baker, L.L.; Strawn, D.G. Lead immobilization and phosphorous availability in phosphate-amended, mine-contaminated soils. J. Environ. Qual. 2015, 8, 183-190. [CrossRef] [PubMed]

22. Cai, M.; McBride, M.B.; Li, K.; Li, Z. Bioaccessibility of as and Pb in orchard and urban soils amended with phosphate, Fe oxide and organic matter. Chemosphere 2017, 173, 153-159. [CrossRef]

23. Li, S.W.; Liu, X.; Sun, H.J.; Li, M.Y.; Zhao, D.; Luo, J.; Li, H.B.; Ma, L.Q. Effect of phosphate amendment on relative bioavailability and bioaccessibility of lead and arsenic in contaminated soils. J. Hazard. Mater. 2017, 339, 256-263. [CrossRef] [PubMed]

24. Kushwaha, A.; Hans, N.; Kumar, S.; Rani, R. A critical review on speciation, mobilization and toxicity of lead in soil-microbe-plant system and bioremediation strategies. Ecotoxicol. Environ. Saf. 2018, 147, 1035-1045. [CrossRef] [PubMed]

25. Park, J.H.; Bolan, N.; Megharaj, M.; Naidu, R. Comparative value of phosphate sources on the immobilization of lead, and leaching of lead and phosphorous in lead contaminated soils. Sci. Total Environ. 2011, 409, 853-860. [CrossRef]

26. Tang, X.; Yang, J. Long-term stability and risk assessment of lead in mill waste treated by soluble phosphate. Sci. Total Environ. 2012, 438, 299-303. [CrossRef] [PubMed]

27. Tekaya, M.; El-Gharbi, S.; Chehab, H.; Attia, F.; Hammami, M.; Mechri, B. Long-term field evaluation of the changes in fruit and olive oil chemical compositions after agronomic application of olive mill wastewater with rock phosphate. Food Chem. 2018, 239, 664-670. [CrossRef]

28. Hettiarachchi, G.M.; Pierzynski, G.M. Soil lead bioavailability and in situ remediation of lead-contaminated soils: A review. Environ. Prog. 2004, 23, 78-93. [CrossRef]

29. Park, J.H.; Bolan, N.; Megharaj, M.; Naidu, R. Isolation of phosphate solubilizing bacteria and their potential for lead immobilization in soil. J. Hazard. Mater. 2011, 185, 829-836. [CrossRef]

30. Bolan, N.S.; Domy, C.A.; Ravi, N. Role of phosphorous in (im)mobilization and bioavailability of heavy metals in the soil plant system. A review. Rev. Environ. Contam. Toxicol. 2003, 177, 1-44.

31. Sterckeman, T.; Douay, F.; Proix, N.; Fourrier, H.; Perdrix, E. Assessment of the contamination of cultivated soils by eighteen trace elements around smelters in the North of France. Water Air Soil Pollut. 2002, 135, 173-194. [CrossRef]

32. Pelfrêne, A.; Waterlot, C.; Douay, F. Influence of land use on human bioaccessibility of metals in smelter-impacted soils. Environ. Pollut. 2013, 178, 80-88. [CrossRef] [PubMed]

33. AFNOR. Soil Quality-Determination of Carbonate Content_Volumetric Method; NF ISO 10693; Association Française de Normalisation: Paris, France, 1995.

34. AFNOR. Soil Quality-Determination of the Cation Exchange Capacity (CEC) and Extractable Cations; NF X31-130; Association Française de Normalisation: Paris, France, 1999.

35. AFNOR. Soil Quality_Determination of Organic and Total Carbon after Dry Combustion (Elementary Analysis); NF ISO 10694; Association Française de Normalisation: Paris, France, 1995.

36. AFNOR. Soil Quality—Determination of Soluble Phosphorus in Ammonium Oxalate 0.1 M-Joret-Hébert Method; NF X 31-161; Association Française de Normalisation: Paris, France, 1993.

37. AFNOR. General Requirements for the Competence of Testing and Calibration Laboratories; NF ISO 17025; Association Française de Normalisation: Paris, France, 2005.

38. USEPA. Method 3050B: Acid Digestion of Sediments, Sludges, and Soils, 2nd ed.; USEPA: Washington, DC, USA, 1996.

39. Feng, M.H.; Shan, X.Q.; Zhang, S.Z.; Wen, B. Comparison of a rhizosphere-based method with other one-step extraction methods for assessing the bioavailability of soil metals to wheat. Chemosphere 2005, 50, 939-949. [CrossRef] [PubMed]

40. Ma, Q.Y.; Traina, S.J.; Logan, T.L.; Ryan, J.A. In situ lead immobilization by apatite. Environ. Sci. Technol. 1993, 27, 1803-1810. [CrossRef]

41. Buscaroli, A. An overview of indexes to evaluate terrestrial plants for phytoremediation purposes (Review). Ecol. Indic. 2017, 82, 367-380. [CrossRef]

42. Cao, X.; Wahbi, A.; Ma, L.; Li, B.; Yang, Y. Immobilization of $\mathrm{Zn}, \mathrm{Cu}, \mathrm{Cu}$ and $\mathrm{Pb}$ in contaminated soils using phosphate rock and phosphoric acid. J. Hazard. Mater. 2009, 164, 555-564. [CrossRef] [PubMed]

43. Waterlot, C.; Douay, F. The problem of arsenic interference in the analysis of Cd to evaluate its extractability in soils contaminated by arsenic. Talanta 2009, 80, 716-722. [CrossRef] [PubMed] 
44. Savio, M.; Cerutti, S.; Martinez, L.D.; Smichowski, P.; Gil, R.A. Study of matrix and spectral interferences in the determination of lead in sediments, sludges and soils by SR-ETAAS using slurry sampling. Talanta 2010, 82, 523-527. [CrossRef] [PubMed]

45. Waterlot, C.; Bidar, G.; Pruvot, C.; Douay, F. Analysis of cadmium in water extracts from contaminated soils with high arsenic and iron concentration levels. J. Environ. Sci. Eng. 2011, 5, 271-280.

46. Douay, F.; Pruvot, C.; Roussel, H.; Ciesielski, H.; Fourrier, H.; Proix, N.; Waterlot, C. Contamination of urban soils in an area of Northern France polluted by dust emissions of two smelters. Water Air Soil Pollut. 2008, 188, 247-260. [CrossRef]

47. Pelfrêne, A.; Waterlot, C.; Mazzuca, M.; Nisse, C.; Cuny, D.; Richard, A.; Denys, S.; Heyman, C.; Roussel, H.; Bidar, G.; et al. Bioaccessibility of trace elements as affected by soil parameters in smelter-contaminated agricultural soils: A statistical modelling approach. Environ. Pollut. 2012, 160, 130-138. [CrossRef] [PubMed]

48. Pelfrêne, A.; Détriché, S.; Douay, F. Combining spatial distribution with oral bioaccessibility of metals in smelter-impacted soils: Implications for human health risk assessment. Environ. Geochem. Health 2015, 37, 49-62. [CrossRef] [PubMed]

49. Waterlot, C.; Pruvot, C.; Ciesielski, H.; Douay, F. Effects of a P amendment and the pH of water used for watering on the mobility and phytoavailability of $\mathrm{Cd}, \mathrm{Pb}$ and $\mathrm{Zn}$ in highly contaminated kitchen garden soils. Ecol. Eng. 2011, 37, 1081-1093. [CrossRef]

50. Chen, S.Y.; Ou, S.F.; Teng, N.C.; Kung, C.M.; Tsai, H.L.; Chu, K.T.; Ou, K.L. Phase transformation on bone cement: Monocalcium phosphate monohydrate into calcium-deficient hydroxyapatite during setting. Ceram. Int. 2013, 39, 2451-2455. [CrossRef]

51. Xu, Y.; Liang, X.; Xu, Y.; Qin, X.; Huang, Q.; Wang, L.; Sun, Y. Remediation of heavy metal-polluted agricultural soils using clay minerals: A review. Pedosphere 2017, 27, 193-204. [CrossRef]

52. Ou, J.; Li, H.; Yan, Z.; Zhou, Y.; Bai, L.; Zhang, C.; Wang, W.; Chen, G. In situ immobilisation of toxic metals in soil using Maifan stone and illite/smectite clay. Sci. Rep. 2018, 8, 4618-4627. [CrossRef] [PubMed]

53. Park, J.H.; Bolan, N.S.; Chung, J.W.; Naidu, R.; Megharaj, M. Environmental monitoring of the role of phosphate compounds in enhancing immobilization and reducing bioavailability of lead in contaminated soils. J. Environ. Monit. 2011, 13, 2234-2242. [CrossRef] [PubMed]

54. Wu, Y.; Zhang, L.; Liu, Y.; Qu, Y. Adsorption mechanisms of metal ions on the potassium dihydrogen phosphate (100) surface: A density functional theory-based investigation. J. Colloid Int. Sci. 2018, 522, 256-263. [CrossRef]

55. Naim Mulana, K.; Fauzjah Ishak, C.; Abu Bakar, R. In-situ immobilization of lead using different source of phosphate amendments for the organic production of misai kucing (Orthosiphon stamineus). Soil Environ. 2017, 36, 20-27. [CrossRef]

56. Shen, J.; Yuan, L.; Zhang, J.; Li, H.; Bai, Z.; Chen, X.; Zhang, W.; Zhang, F. Phosphorous Dynamics: From soil to plant. Plant Physiol. 2011, 156, 997-1005. [CrossRef]

57. Hodgson, J.F. Chemistry of the micronutrient elements in soils. Adv. Agron. 1963, 15, 119-159.

58. Haby, V.A.; Russelle, M.P.; Skogley, E.O. Soil Testing for Potassium, Calcium and Magnesium. In Soil Testing and Plant Analysis; Westerman, R.L., Ed.; Soil Science Society of America Inc.: Madison, WI, USA, 1990; pp. 181-227.

59. Tripathy, D.K.; Singh, V.P.; Chauhan, D.K.; Prasad, S.M.; Dubey, N.K. Role of macronutrients in plant growth and acclimation: Recent advances and future prospective. In Improvement of Crops in the Era of Climatic Changes; Ahmad, P., Wani, M.R., AzoozMM, L.-S.T., Eds.; Springer: Berlin/Heidelberg, Germany, 2014; pp. 197-216.

60. Leigh, R.A.; Wyn Jones, R.G. A hypothesis relating critical potassium concentrations for growth to the distribution and functions of this ion in the plant cell. New Phytol. 1984, 97, 1-13. [CrossRef]

61. Vose, P.B. The cation content of perennial ryegrass Lolium Perenne L. in relation to intraspecific variability and nitrogen/potassium interaction. Plant Soil 1963, 19, 49-64. [CrossRef]

62. Kidambi, S.P.; Matches, A.G.; Griggs, T.C. Variability for $\mathrm{Ca}, \mathrm{Mg}, \mathrm{K}, \mathrm{Cu}, \mathrm{Zn}$ and $\mathrm{K} /\left(\mathrm{Ca}^{+} \mathrm{Mg}\right)$ ratio among 3 wheatgrasses and sainfoin on the southern high plains. Rangel. Ecol. Manag. 1989, 42, 316-322. [CrossRef]

63. Barnum, D.W. Hydrolysis of cations. Formation constants and standard free energies of formation of hydroxy complexes. Inorg. Chem. 1983, 22, 2297-2305. [CrossRef] 
64. Tyler, G. Ionic charge, radius, and potential control root/soil concentration ratios of fifty cationic elements in the organic horizon of a beech (Fagus Sylvatica) forest podzol. Sci. Total Environ. 2004, 329, 231-239. [CrossRef] [PubMed]

65. Waterlot, C.; Bidar, G.; Pelfrêne, A.; Roussel, H.; Fourrier, H.; Douay, F. Contamination, fractionation and availability of metals in urban soils in the vicinity of former lead and zinc smelters, France. Pedosphere 2013, 23, 143-159. [CrossRef]

66. Nardi, S.; Concheri, G.; Pizzeghello, D.; Sturaro, A.; Rella, R.; Parvoli, G. Soil organic matter mobilization by root exudates. Chemosphere 2000, 41, 653-658. [CrossRef]

67. Hinsinger, P.; Plassard, C.; Tang, C.; Jaillard, B. Origins of root-mediated pH changes in the rhizosphere and their response to environmental constraints: A review. Plant Soil 2003, 248, 43-59. [CrossRef]

68. Marschner, H.; Romheld, V.; Horst, W.J.; Martin, P. Root-induced changes in the rhizosphere: Importance for the mineral nutrition of plants. J. Plant Nutr. Soil Sci. 1986, 149, 441-456. [CrossRef]

69. Chang, A.C.; Page, A.L.; Koo, B.J. Biogeochemistry of phosphorous, iron, and trace elements as influenced by soil-plant-microbial interactions. In Soil Mineral-Organic Matter-Microorganism Interactions and Ecosystem Health: Ecological Significance of the Interactions Among Clay Minerals, Organic Matter and Soil Biota; Violante, A., Huang, P.M., Bollag, J.M., Gianfreda, L., Eds.; Developments in Soil Science; Elsevier: Amsterdam, The Netherlands, 2002; pp. 43-57.

70. Violante, A.; Huang, P.M.; Bollag, J.M.; Gianfreda, L. Soil Mineral-Organic Matter-Microorganism Interactions and Ecosystem Health: Dynamics, Mobility and Transformations of Pollutants and Nutrients; Developments in Soil Science; Elsevier: Amsterdam, The Netherlands, 2002.

71. Fan, C.; Zhang, Y. Environmentally friendly remediation of lead/cadmium co-contaminated loess soil in northwestern China using a humificated straw solution. Environ. Sci. Pollut. Res. 2018, 25, 25243-25254. [CrossRef] [PubMed]

72. Farid, M.; Ali, S.; Zubair, M.; Saeed, R.; Rizwan, M.; Sallah-Ud-Din, R.; Azam, A.; Ashraf, R.; Ashraf, W. Glutamic acid assisted phyto-management of silver contaminated soils through sunflower; physiological and biochemical response. Environ. Sci. Pollut. Res. 2018, 25, 25300-25400. [CrossRef] [PubMed]

73. Jones, D.L. Organic acids in the rhizosphere-A critical review. Plant Soil 1998, 205, 25-44. [CrossRef]

74. Kutrowska, A.; Szelag, M. Low-molecular weight organic acids and peptides involved in the long-distance transport of trace metals. Acta Physiol. Plant. 2014, 36, 1957-1968. [CrossRef]

75. Li, Y.; Hou, Y.; Song, X.; Sun, L.; Li, S.; Guo, Q.; Hu, X. Effect of pH on the desorption of trace metals by different LMWOAs from a field soil. Adv. Mater. Res. 2015, 1073, 193-196. [CrossRef]

76. Shan, X.-Q.; Wang, Z.; Wang, W.; Zhang, S.; Ben, W. Labile rhizosphere soil solution fraction for prediction of bioavailability of heavy metals and rare earth elements to plants. Anal. Bioanal. Chem. 2003, 375, 400-407. [CrossRef] [PubMed]

77. Abedin, J.; Beckett, P.; Spiers, G. An evaluation of extractants for assessment of metal phytoavailability to guide reclamation practices in acidic soilscapes in northern regions. Can. J. Soil Sci. 2012, 92, 253-268. [CrossRef]

78. Vásquez, S.; Moreno, E.; Carpena, R.O. Bioavailability of metals and as from acidified multicontaminated soils: Use of white lupin to validate several extraction methods. Environ. Geochem. Health 2008, 30, 193-198. [CrossRef]

79. Pérez-Esteban, J.; Escolástico, C.; Moliner, A.; Masaguer, A.; Ruiz-Fernández, J. Phytostabilization of metals in mine soils using Brassica juncea in combination with organic amendments. Plant Soil 2014, 377, 97-109. [CrossRef]

80. Cieslinski, G.; Van Rees, K.C.J.; Szmigielska, A.M.; Krishnamurti, G.S.R.; Huang, P.M. Low-molecular-weight organic acids in rhizosphere soils of durum wheat and their effect on cadmium bioaccumulation. Plant Soil 1998, 203, 109-117. [CrossRef]

81. Soriano-Disla, J.M.; Gómez, I.; Navarro-Pedreno, J. Use of a rhizosphere-based method for the assessment of heavy-metal bioavailability in soils amended with polluted sewage sludge. Commun. Soil Sci. Plant Anal. 2013, 44, 1599-1609. [CrossRef]

82. Hechelski, M.; Ghinet, A.; Louvel, B.; Dufrénoy, P.; Rigo, B.; Daïch, A.; Waterlot, C. From Conventional Lewis acids to heterogeneous montmorillonite $\mathrm{K} 10$, eco-friendly plant-based catalysts used as green Lewis acids. ChemSusChem 2018, 11, 1249-1277. [CrossRef] [PubMed] 
83. Deyris, P.A.; Bert, V.; Diliberto, S.; Boulanger, C.; Petit, E.; Legrand, Y.M.; Grison, C. Biosourced polymetallic catalysis: A surprising and efficient means to promote the Knoevenagel condensation. Front. Chem. 2018, 6, 1-9. [CrossRef] [PubMed]

84. Deyris, P.A.; Grison, C. Nature, ecology and chemistry: An unusual combination for a new green catalysis, ecocatalysis. Curr. Opin. Green Sustain. Chem. 2018, 10, 6-10. [CrossRef]

85. Hazotte, C.; Laubie, B.; Rees, F.; Morel, J.L.; Simonnot, M.O. A novel process to recover cadmium and zinc from the hyperaccumulator plant Noccaea caerulescens. Hydrometallurgy 2017, 174, 56-65. [CrossRef]

86. Vaughan, J.; Riggio, J.; Chen, J.; Peng, H.; Harris, H.H.; Van der Ent, A. Characterisation and hydrometallurgical processing of nickel from tropical agromined bio-ore. Hydrometallurgy 2017, 169, 346-355. [CrossRef]

87. Guilpain, M.; Laubie, B.; Zhang, X.; Morel, J.L.; Simonnot, M.O. Speciation of nickel extracted from hyperaccumulator plants by water leaching. Hydrometallurgy 2018, 180, 192-200. [CrossRef]

88. Jakovljević, M.D.; Kostić, N.M.; Antić-Mladenović, S.B. The availability of base elements (Ca, Mg, Na, K) in some important soil types in Serbia, Proceedings for Natural Sciences. Zbornik Matice Srpske Za Prirodne Nauke 2003, 104, 11-21. [CrossRef]

89. Jungk, A.; Claassen, N. Availability of phosphate and potassium as the result of interactions between root and soil in the rhizosphere. J. Plant Nutr. Soil. Sci. 1986, 149, 411-427. [CrossRef]

90. Mitsios, I.K.; Rowell, D.L. Plant uptake of exchangeable and non-exchangeable potassium. I. Measurement and modelling for onion roots in a Chalky Boulder clay soil. J. Soil. Sci. 1987, 38, 53-63. [CrossRef]

91. Treeby, M.; Marschner, H.; Romheld, V. Mobilization of iron and other micronutrient cations from a calcareous soil by plant-borne, microbial, and synthetic metal chelators. Plant Soil 1989, 114, 217-226. [CrossRef]

92. Naidu, R.; Harter, R.D. Effect of different organic ligands on cadmium sorption by and extractability from soils. Soil Sci. Soc. Am. J. 1998, 62, 644-650. [CrossRef]

93. Tester, M. Tansley Review No. 21-Plant ion channels: Whole-cell and single channel studies. New Phytol. 1990, 114, 305-340. [CrossRef]

94. Yoon, J.; Cao, X.; Zhou, Q.; Ma, Q.L. Accumulation of $\mathrm{Pb}, \mathrm{Cu}$ and $\mathrm{Zn}$ in native plants growing on a contaminated Florida site. Sci. Total Environ. 2006, 368, 456-464. [CrossRef] [PubMed]

95. Jia, Y.; Tang, S.; Wang, R.; Ju, X.; Ding, Y.; Tu, S.; Smith, D.L. Effects of elevated on growth, photosynthesis, elemental composition, antioxidant level, and phytochelatin concentration in Lolium multiforum and Lolium perenne under Cd stress. J. Hazard. Mater. 2010, 180, 384-394. [CrossRef]

96. Sarret, G.; Balesdent, J.; Bouziri, L.; Garnier, J.M.; Marcus, M.A.; Geoffroy, N.; Panfili, F.; Manceau, A. $\mathrm{Zn}$ speciation in the organic horizon of a contaminated soil by Micro-X-ray Fluorescence, micro- and power-EXAFS Spectroscopy, and isotopic dilution. Environ. Sci. Technol. 2004, 38, 2792-2801. [CrossRef]

97. Couder, E.; Mattielli, N.; Drouet, T.; Smolders, E.; Delvaux, B.; Iserentant, A.; Meeus, C.; Maerschalk, C.; Opfergelt, S.; Houben, D. Transpiration flow controls Zn transport in Brassica napus and Lolium multiflorum under toxic levels as evidenced from isotopic fractionation. C. R. Geosci. 2015, 347, 386-396. [CrossRef]

98. Kř́ibek, B.; Šípková, A.; Ettler, V.; Mihaljevič, M.; Majer, V.; Knési, I.; Mapanu, B.; Penížek, V.; Vaněk, A.; Sracek, O. Variability of the copper isotopic composition in soil and grass affected by mining and smelting in Tsumeb, Namibia. Chem. Geol. 2018, 493, 121-135. [CrossRef]

99. Escande, V.; Olszewski, T.K.; Grison, C. Preparation of ecological catalysts derived from Zn hyperaccumulating plants and their catalytic activity in Diels-Alder reaction. C. R. Chim. 2014, 17, 731-737. [CrossRef]

100. Oustrière, N.; Marchand, L.; Roulet, E.; Mench, M. Rhizofiltration of a Bordeaux mixture effluent in pilot-scale constructed wetland using Arundo donax L. coupled with potential Cu-ecocatalyst production. Ecol. Eng. 2017, 105, 296-305. [CrossRef]

(C) 2019 by the authors. Licensee MDPI, Basel, Switzerland. This article is an open access article distributed under the terms and conditions of the Creative Commons Attribution (CC BY) license (http://creativecommons.org/licenses/by/4.0/). 